\title{
LA CONCURRENCIA DE ACCIONES REALES Y LA POSESIÓN MATERIAL*
}

\section{RODRIGO BARCIA LEHMANN ${ }^{* *}$}

RESUMEN: El presente trabajo analiza fallos de la CS del 2010 hasta el 2015 en adelante para detectar los criterios conforme a los cuales, tribunales discrimina entre acciones reales similares. En la mayoría de las sentencias analizadas, el criterio fundamental en torno a la concurrencia de acciones reales es <<la posesión material $>$ de la cosa. A su vez, dichos fallos establecen que la acción reivindicatoria es la acción que por antonomasia protege el dominio, no solo respecto de la posesión, sino también respecto de la detentación material. Esta jurisprudencia constante de la $C S$ ha puesto en dudas fuertemente la teoría de la posesión inscrita y, eventualmente afecta la eficiencia del sistema de acciones reales, por cuanto muchas acciones y fallos, sobre todo de la $C A$, siguen sustentándose en la referida teoría de la posesión inscrita.

PALABRAS CLAVE: Posesión inscrita - acción reivindicatoria - posesión material

\section{THE CONCURRENCE OF REAL ACTIONS AND THE MATERIAL POSSESSION}

ABSTRACT: This paper examines several sentences of the Supreme Court from 2010 to 2015 onwards to detect the criteria according to which courts discriminate between similar real actions. In most of the

\footnotetext{
* Fecha de recepción: 27 de enero de 2016. Fecha de aceptación: 9 de mayo de 2016.

El presente artículo corresponde al Fondecyt Regular N 1.130.178, 2013-2015, "Reconstrucción de la idea de la posesión en el CC chileno", Dr. Atria (investigador responsable).

** Profesor Titular y Dr. de Derecho Civil, Facultad de Derecho, Universidad Finis Terrae. Dirección postal: Avenida Pedro de Valdivia No 1509, Providencia, Chile. Correo electrónico: rbarcia@uft.cl

Se agradece a Flavia Urqueta, ayudante de investigación, su invaluable ayuda en la revisión de la jurisprudencia. La mayoría de las sentencias no fueron obtenidas en bases de datos, sino directamente de la página del Poder Judicial.
} 
sentences, the fundamental criterion analyzed was that the concurrence of real action is the "material possession" of the thing. These sentences, in turn, establishes that the vindication action is the one that protects the domain par excellence, not only with regards to the possession, but also with regards to the material possession. This continuous jurisprudence of the Supreme Court has strongly cast doubt on the registered possession theory, which eventually affects the efficiency of the system of real actions as a consequence of that many actions and sentences are still underpinned by the registered possession theory, particularly the ones from the APPELLATE Courts.

KEY WORDS: Registered possession - vindication action - material possession

Sumario: Introducción. 1) Dificultad de la jurisprudencia de los tribunales superiores en torno a fijar los criterios que determinan la concurrencia de acciones reales. 2) La <<detentación material de la cosa $>>0<<$ posesión material >> como criterio fundamental de los tribunales superiores para resolver problemas de concurrencia de acciones reales. (2.1.) Ámbito de aplicación de la acción de demarcación y cerramiento, por una parte, y la acción reivindicatoria, por la otra: Declinación de la teoría de la posesión inscrita a favor de una tesis voluntarista de la posesión basada en el artículo 700 CC. (2.1.1.) Fallo Corte de Apelaciones de Talca. 5 de abril de 2010. Rol $N^{\circ}$ 1.286-2009. "Ramírez con Berrios". (2.1.2.) Fallo Corte Suprema. 9 de abril de 2013. Rol $N^{\circ}$ 573-2013. "Inversiones José de Logroño Limitada con Carvajal”. (2.1.3.) Fallo Corte Suprema. 13 de agosto de 2013. Rol $N^{\circ}$ 6.826-2012. "Jarpa con Jarpa". (2.1.4.) Fallo Corte Suprema. 17 de marzo de 2014. Rol $N^{\circ}$ 16.816-2013. "Inmobiliaria Portabello con Navarrete". (2.1.5.) Fallo Corte Suprema. 17 de junio de 2014. Rol $N^{\circ}$ 2.422-2013. "Parra con Parra". (2.1.6.) Fallo Corte Suprema. 24 de junio de 2014. Rol $N^{\circ}$ 178-2014. "Montiel con Baez". (2.1.7.) Fallo Corte de Apelaciones de Valdivia. 5 de octubre de 2015. Rol No 968-2015. "Collado con Gallego". (2.1.8.) Conclusiones parciales. (2.2.) Reversión de la tendencia del desplazamiento de la acción reivindicatoria por la acción de simple precario. (2.2.1.) Fallo Corte Suprema. 1 de septiembre de 2010. Rol No 7.219-2008. "Tallar con Benzanilla”. (2.2.2.) Fallo Corte Suprema. 19 de diciembre de 2012. Rol No 6.860-2011. "Oliver con Molina" y Corte de Apelaciones de San Miguel. 25 de junio de 2014. Rol No 214-2014. "Lara con Aránquiz". (2.2.3.) Fallo Corte Suprema. 15 de enero de 2014. Rol No 13.741-2013. "Inversiones e Inmobiliaria Carla con Servicios Gráficos" y de la Corte de Apelaciones de San Miguel. 10 de agosto de 2011. Rol No 455-2011. "Moraga con Inmobiliaria Ltda.”. (2.2.4.) Fallo Corte Suprema. 19 de marzo de 2015. Rol 
$N^{\circ}$ 10.619-2014. "Polanco con Saavedra". (2.2.5.) Fallo Corte Suprema. 6 de julio de 2015. Rol $N^{\circ}$ 25.669-2014. "Olivares con Olivares". (2.2.6.) Conclusiones parciales. (2.3.) Ámbito preferente de la acción de saneamiento: ¿Un dominio preferente? (2.3.1.) Fallo Corte Suprema. 20 de noviembre de 2013. Rol No 7.528-2012. "Banco de Chile con Villanueva". (2.3.2.) Fallo Corte de Apelaciones de Santiago. 14 de octubre de 2014. Rol $N^{\circ} 8.401-$ 2013. "Valdera con Novoa". (2.3.3.) Fallo Corte Suprema. 22 de enero de 2014. Rol No 6.553-2013. "Forestal Tierra Chilena Ltda., con Aguilar Vidal Maria Lugardina y otros". (2.3.4.) Fallo Corte Suprema. 30 de enero de 2014. Rol $N^{\circ}$ 1.1246-2013. "Lozano con Quezada". (2.3.5.) Conclusiones parciales. (2.4.) Determinación de la concurrencia de las querellas de amparo y restitución. (2.4.1.) Fallo Corte de Apelaciones de Rancagua. 31 de diciembre de 2010. Rol No 915-2010. "Agrícola y Ganadera con Cruz". (2.4.2.) Fallo Corte Suprema. 25 de junio de 2013. Rol No 7.116-2012. "Sociedad Pigmentos Naturales con Guagama”. (2.4.3.) Fallo Corte Suprema. 30 de abril de 2014. Rol $N^{\circ}$ 13.721-2013. "Pizarro con Vergara". (2.4.4.) Conclusiones parciales. 3) Conclusiones. Bibliografia.

\section{INTRODUCCIÓN}

El presente trabajo se centra en la protección de los derechos reales, a través de la concurrencia de acciones reales, respecto de la posesión inscrita. Para el logro del referido objetivo se busca, por una parte, determinar como estaría operando la teoría de la posesión inscrita, y, por la otra, analizar si los tribunales están actuando con estándares adecuados de eficacia. La eficacia dice relación con la adscripción o no de los fallos que se analizan -que son casi la totalidad de los fallos de la $C S$ en el período analizado ${ }^{1}$ - a la referida teoría de la posesión inscrita, dado como antecedente el alto grado de adhesión que dicha teoría genera en nuestra doctrina.

Esta investigación es el resultado de un proyecto de investigación en el que se sostiene que el sistema de Bello, respecto de la propiedad raíz, es dual. Existen, por una parte, los inmuebles adscritos al régimen de propiedad no inscrita, es decir, al sistema constituido por el artículo $700 \mathrm{CC}$, y, por la otra, al régimen de propiedad inscrita, que se rige por la teoría de la posesión inscrita. El primero de estos regímenes, como previó Bello, estaría destinado a desaparecer, desde que hoy, a lo menos en las ciudades, la propiedad y la posesión son registrales. Así, se cumpliría con la promesa manifestada en el Mensaje del Código, por la cual se llegarían "aceleradamente a una época en que inscripción, posesión y propiedad serían

Como aspecto metodológico se han analizado todas las sentencias de la CS en el período entre 2010-2015 con relación a las acciones reales que se indican. 
términos idénticos". Sin embargo, el sistema registral lejos de ser una panacea ha dado lugar a una tensión, que se resiste a aplacarse. Ella se produce entre poseedor inscrito y detentador o tenedor material, que tiene ánimo de señor y dueño. Esta tensión ha sido abordada, por una parte, a través de la ley, como sucede en el saneamiento de la pequeńa propiedad, y, por la otra, a través de tribunales. Nuestro más alto tribunal ha otorgado al detentador un estatus, que ha sido resistido por la teoría de la posesión inscrita, como lo es de $<<$ poseedor material $>>$.

Esta investigación evidencia que el gran catalizador de las categorías normatizadas de posesión, que dio lugar a la teoría de la posesión inscrita, han sido puestas en tela de juicio, por la CS. Las sentencias del más alto tribunal han desplazado, o complementado si se quiere, la posesión inscrita por la $<<$ posesión material $>>$ en cuanto a la concurrencia de las acciones reales que se analizan.

\section{1) Dificultad DE LA JURISPRUDENCIA DE LOS TRIBUNALES SUPERIORES EN TORNO A FIJAR LOS CRITERIOS QUE DETERMINAN LA CONCURRENCIA DE ACCIONES REALES}

La doctrina chilena hace tiempo que viene detectando una serie de problemas en torno a la protección del dominio ${ }^{2}$. Dichos problemas tienen que ver con las acciones deducidas con relación a los conflictos entre, por una parte, el dominio, y, por la otra, la posesión y tenencia material. La tensión se debe solucionar a favor del dueńo, por cuanto el ordenamiento jurídico debe propender a que el dominio no esté desprovisto, ni de la posesión, ni de la tenencia. Esta tensión se presenta respecto de la siguiente concurrencia de acciones: (1) ámbito de aplicación de las acciones de demarcación y cerramiento, por una parte, y reivindicatoria, por la otra; (2) desplazamiento de la acción reivindicatoria por la de simple precario, y reversión de esta tendencia ${ }^{3}$; (3) determinación de la concurrencia de las acciones posesorias de amparo y restitución; (4) ámbito preferente de la acción de saneamiento; y (5) acciones reales atípicas ${ }^{4}$.

2 Atria, Fernando (2005) "Derechos reales", Revista de Derecho de la Universidad Adolfo Ibáñez, número 2; Comentario de la jurisprudencia del año 2004, Legis, Peñalolén y Viña del Mar, pp. 70 a 76; "La tierra para el que la trabaja", Barros, Figueroa, Tapia (coordinadores): Estudios de Derecho Civil VI, Jornadas Nacionales de Derecho Civil, Abeledo Perrot, LegalPublishing Chile, Santiago de Chile, 2011, pp. 229 a 236.

3 Se deja fuera del presente análisis el conflicto entre la acción de simple precario, y la oposición del dueño en el procedimiento de saneamiento (artículo 19 DL 2.695), que será tratado por el investigador principal del Proyecto.

4 Estas acciones, muy importantes en el Derecho comparado, y que podrían dar una solución a los conflictos precedentemente planteados no serán abordadas dado que exceden la presente investigación. Lathrop, Fabiola (2011) "Procedencia de la acción meramente declarativa 
La concurrencia de acciones ha generado una gran incertidumbre en la aplicación del Derecho Civil, desde que es común, que un dueño que busca recuperar la posesión o la tenencia, se vea entrampado en una marańa de acciones que hacen ilusorio su derecho. Esta maraña tiene su origen en una confusión en torno a la procedencia de acciones, que se traduce en un exceso de litigación, como se aprecia en dos situaciones. En algunos casos los tribunales, frente a casos dudosos, desechan acciones reales para recuperar la tenencia y en otros, la acción es acogida después de intentar una o más de una acción. En la primera situación, la $C S$ ha rechazado acciones de demarcación y cerramiento entre vecinos por estimar que procede acción reivindicatoria; se ha desechado la acción de simple precario, también a favor de la acción dominical5; se hacen exigencias probatorias imposibles de cumplir en el precario ${ }^{6}$ o se desecha la acción de precario por estimar que procede el simple precario ${ }^{7}$. En igual sentido,

del dominio en el derecho chileno", Revista Ius et Praxis, Año 17, № 2, pp. 3-24. Lathrop señala como ejemplo de acción declaratoria de dominio a aquellas que ejerce el dueño comodante contra el comodatario, respecto del cual la acción de precario está prescrita. En este supuesto el dueńo comodante busca la declaración del dominio como un caso previo a la restitución. Al parecer la autora consideraría que la acción de precario, ya prescrita, reviviría. Lathrop (2011) 15.

5 Así, la CS ha considerado que en caso que el demandado tenga la <<posesión material >> procedería la acción reivindicatoria, en lugar de la acción de simple precario. CS. Rol $\mathrm{N}^{\circ} 10.619-2014$.

6 A este respecto Larroucau y Rostión señalan que la sentencia de Corte Suprema. 12 de enero de 1981. "Salamanca con Salamanca", citada en RDJ, tomo, LXXXVIII, segunda parte, sección $1^{\text {a }}$, cons. $1^{\circ}$ y $2^{\circ}$, pp. $5-7$, rechaza una demanda de precario por considerar la controversia en términos tales que solo podían dilucidarse en un juicio de lato conocimiento. Ello se debía a que a pesar que a la inscripción cumplía con creces el tiempo para dar lugar a la prescripción adquisitiva, la CORTE exigió acreditar el dominio del tradente. En realidad, la crítica al fallo puede ir un poco más lejos por cuanto no es que dicha prueba solo pueda darse en un juicio de lato conocimiento -haciendo que el precario se entable conforme a dichas reglas-, sino que impide acreditar la adquisición de la cosa por tradición. Ello se debe a que la única forma de acreditar el dominio sería demandar, en el propio juicio o en uno previo, la prescripción adquisitiva. Lo anterior se debe a que la única forma de acreditar el dominio en la tradición es mediante la prueba de la concurrencia de los elementos de la prescripción adquisitiva, por cuanto la tradición solo transfiere el dominio, si el tradente es dueño de la cosa. Larroucau, Jorge y Rostión, Ignacio (2013) "Del juicio de precario", BARCia, Rodrigo, (Coordinador) Fundamento de Derechos Reales en el Derecho Chileno, Editorial Thomson Reuters, pp. 84-85. En contra de esta idea se manifiesta explícitamente Larroucau. Larroucau, Jorge (2014) "La 'prueba completa' del dominio en la acción reivindicatoria", Turner y Varas (coordinadores) Estudios de Derecho Civil IX, Thomson Reuters, Santiago de Chile, pp. 103-123.

7 El fallo Corte Suprema. 12 de agosto de 2013. Rol No 174-2013. "Ramírez con Zapata", resuelve: "Iq]ue en la línea propuesta y constituyendo un hecho de la causa que existió entre el actor y Leonor (...) un vinculo de carácter contractual, en que el primero entregó a la segunda el predio para que fuese habitado por la promitente compradora, es posible colegir que aun cuando el demandado no tenía la calidad de parte en el contrato preparatorio en cuestión, es precisamente dicho contrato el que desplaza la figura jurídica en análisis, desde que este naturalmente, en virtud de la autorización que aquella le confirió para la tenencia del mismo, lo ocupa, no por la mera tolerancia, simple condescendencia o aceptación del dueño, sino que en virtud de un 
la sentencia Corte Suprema. 1 de julio de 2011. Rol No 7.149-2010. "Yáńez con Tocornal", resuelve que, si se acredita la existencia de un contrato de comodato, la acción de precario es improcedente, y corresponde la de comodato precario ${ }^{8}$.

En un segundo grupo de sentencias la acción real es acogida después que se han desestimado una o varias acciones. Así, el fallo de la Corte Suprema. 17 de junio de 2014. Rol N².422-2013. "Parra con Parra", resuelve que: “...[p] or lo demás, si no ha podido el contrato de promesa justificar la ejecución de los actos de dominio que describe el fallo que se revisa, tampoco puede la demandada nuevamente esgrimir dicho titulo que ya habia invocado en el anterior juicio de precario como justificación de su permanente ocupación del inmueble y la subsecuente privación de la posesión material a su dueña, quien ha perseguido la restitución de lo que le pertenece por diferentes vias, sin éxito, sin poder olvidarse que, con todo, la acción impetrada en autos también se funda en la situación que regula el artículo 915 del Código Civil' (considerando $7^{\circ}$ ) 9 . En igual sentido se puede consultar la sentencia Corte Suprema. 20 de enero de 2015. Rol No 11.995-14. "Quercus S.A. con Bazan"10.

acuerdo del que es parte quien con su anuencia le ha permitido la tenencia del predio desde hace más de diez años, según lo declara el testigo del actor que compareció a estrados, de manera que pese a no haber concurrido personal y directamente a su celebración, claramente la cadena de vinculos jurídicos a la que se ha hecho alusión impiden la concurrencia del precario, puesto que si el concepto de mera tolerancia se revela en la circunstancia que el ocupante tiene la cosa ajena porque el dueño de esta lo deja proceder de ese modo, es decir, no se opone y, como quiera que es precisamente ese cariz radical el que no puede faltar a la hora de analizar la hipótesis que se pide calificar de simple precario, es innegable que ella no concurre en el caso que la ocupación que el demandado no niega respecto del inmueble indicado en el libelo pretensor, se encuentra precedida de un acuerdo de voluntades que le ha servido de causa y que tiene previstos efectos en el ámbito del derecho..." (considerando $13^{\circ}$ ).

8 La CS acogió un recurso de casación en la forma por $<<$ ultra petita $>>$ contra la sentencia de segunda instancia, por cuanto la demanda al ser de comodato precario no puede el tribunal acogerla como de simple precario.

9 Esta tendencia no es definitiva, desde que la Corte en otros fallos ha estimado que no incurre en $<<$ ultra petita $>>$ el juez que acoge una acción reivindicatoria por fundamentos diferentes a los planteados en la demanda. En este sentido se puede consultar una sentencia de la $C S$ en que se rechaza una casación en la forma interpuesto contra una sentencia de CorTE de Apelaciones de Rancagua. 22 de abril de 2014. El fallo de segunda instancia acogió un recurso de apelación contra la sentencia del tribunal $<<a q u o>>$, de 22/03/13. La sentencia de primera instancia rechazó una acción reivindicatoria por estimar a la demandada como ocupante, y no como poseedora. A pesar que la apelación no se sustentaba en el artículo 915 CC, referente al injusto detentador, la sentencia de segunda instancia resolvió otorgarle dicha calidad a la demandada y dar lugar al libelo de reivindicación. Frente a ello la demandada recurre de casación ante la $C S$ (ver considerandos $7^{\circ}$ y $8^{\circ}$ ).

10 En un juicio ante el Primer JLC de Rengo, Rol N³20-2011, la Sociedad Quercus S.A. dedujo demanda en juicio ordinario de reivindicación en contra de María (...), a fin de que se declarara el dominio de la actora sobre el inmueble ocupado por la demandada. La demandada contestó señalando que no procedía la acción reivindicatoria por cuanto no era poseedora, ya que reconocía dominio ajeno. Indica que ocupa el inmueble objeto del juicio 
En otros casos, los tribunales han desechado una segunda acción real por considerar que hay cosa juzgada. El fallo Corte de ApelaCiones DE Temuco. 11 de agosto de 2014. Rol No 1142-2013. "Inmobiliaria con Núñez", desechó una acción reivindicatoria, al existir cosa juzgada material sobre la prueba del dominio en el precario ${ }^{11}$. El fallo Corte SupreMA. 14 de enero de 2015. Rol No 26.690-2014. "Cabrini con Isapre Cruz Blanca”, confirmaría dicha sentencia ${ }^{12}$.

Estas soluciones de nuestra jurisprudencia son criticables desde que lamentablemente nosotros no contamos con un claro sistema de acciones reales, como se puede apreciar en el presente trabajo, lo que hace que los derechos reales pierdan su característica eficiencia ${ }^{13}$.

en razón de la transacción, de 19/11/99, que celebró con su ex marido, Juan (...), socio mayoritario y representante de Quercus S.A., en el contexto de un juicio de alimentos. En dicho acuerdo se convino que el inmueble sería declarado bien familiar y se constituiría un usufructo a su favor, pero la transacción no fue cumplida por Juan. Además agrega que en el ańo 2007 la demandada solicitó la declaración de bien familiar sobre el mismo inmueble, acción que fue rechazada, pues a esa época su ex marido ya había transferido sus acciones en la sociedad. La juez subrogante del tribunal referido en el primer apartado, mediante sentencia de 22/03/13, desestimó la acción reivindicatoria. Apelada dicha sentencia por la demandante, la $C A$ de Rancagua, en decisión de 22/04/14, acogió la demanda, revocando la sentencia de primera instancia. La demandada recurre de casación en la forma, que fue rechazado. La CS, en el considerando $7^{\circ}$, resuelve: “...en efecto, aun cuando la actora fundara su pretensión en lo prevenido en los artículos 889 y ss. CC, la calificación jurídica de los hechos propuestos por las partes en sus escritos fundamentales corresponde exclusivamente al tribunal, en virtud del principio denominado jura novit curia, ya que al juez corresponde aplicar el derecho, de modo que al acoger la pretensión sobre la base de lo estatuido por el artículo 915 del código sustantivo, los sentenciadores no se han apartado de los tópicos de la controversia, ni se han extendido a puntos no sometidos a su decisión (...) La doctrina de tal manera asentada por la jurisprudencia sobre la materia en estudio cobra especial vigor en una situación como la que evidencian estos autos, donde consta que, antes de promover el presente juicio reivindicatorio, la actora ya habia intentado recuperar la posesión del bien deduciendo en contra de la demandada una acción de precario, pretensión que, en definitiva, no prosperó, por estimarse que esta última contaba con un título que justificaba su ocupación, antecedente que, en ese contexto, era suficiente para enervar la acción".

11 Este fallo resuelve que, a pesar que ambas acciones tienen una causa de pedir diferente -la acción reivindicatoria la restitución de la posesión y la de simple precario de la tenencia material-, la falta de la acreditación del dominio, en la acción reivindicatoria, generaría cosa juzgada respecto del simple precario, por cuanto ambas acciones requieren de la prueba del dominio.

Ver considerandos $10^{\circ}$ a $17^{\circ}$.

12 La CS, rechazó el recurso de casación, resolviendo: “...Asimismo, concluyen que los hechos narrados por la actora en ambos juicios son exactamente los mismos: en los dos se alega la ocupación de un retazo de terreno por parte del demandado, sin titulo alguno; en uno y otro caso se reconoce la tenencia del terreno por el demandado desde antes de la adquisición del inmueble sublite por la actora y en ambos se funda el dominio que hace nacer la acción de precario o la acción reivindicatoria, en virtud de un contrato de compraventa otorgado por escritura pública de fecha 25/02/91, lo que confirma la identidad de la causa de pedir que desconoce la recurrente" (considerando $3^{\circ}$ ).

13 Martínez señala la solución de la doctrina y la jurisprudencia española frente a un caso similar: la confusión de procedencia entre las acciones reivindicatoria y de mera declaración del dominio. La referida autora indica que: "[e]n la práctica forense, la separación entre 
En resumen, estos problemas, aunque son prácticos, hunden sus raíces en aspectos teóricos. Y ello, en parte, se deben a la separación artificial entre $<<$ la posesión material $>>$, establecida en el artículo 700 CC -que exige $<<$ corpus $>>$ y $<<$ animus $>>-$, y la posesión ideal elaborada en el Código de Bello, a través de las normas que establecen lo que nuestra doctrina ha denominado como teoría de la posesión inscrita. El presente trabajo explicita los criterios de la jurisprudencia en torno a la concurrencia de acciones reales.

\section{2) LA $<<$ DETENTACIÓN MATERIAL DE LA COSA>> O < POSESIÓN MATERIAL > COMO CRITERIO FUNDAMENTAL DE LOS TRIBUNALES SUPERIORES PARA RESOLVER PROBLEMAS DE CONCURRENCIA DE ACCIONES REALES}

A continuación se analizarán los problemas de concurrencia de acciones reales, especialmente respecto de la tensión entre la posesión material e inscrita.

\section{(2.1.) ÁMBITO DE APLICACIÓN DE LA ACCIÓN DE DEMARCACIÓN Y CERRAMIENTO, POR UNA PARTE, Y LA ACCIÓN REIVINDICATORIA, POR LA OTRA: DECLINACIÓN DE LA TEORÍA DE LA POSESIÓN INSCRITA A FAVOR DE UNA TESIS VOLUNTARISTA DE LA POSESIÓN BASADA EN EL ARTÍCULO 700 CC}

En nuestro Derecho se ha generado una soterrada batalla respecto del ámbito de aplicación de las acciones reales señaladas precedentemente. Ello, por cuanto la CS lejos de adscribirse a la teoría de la posesión

acción reivindicatoria y declarativa de dominio no es tan evidente, y en muchas ocasiones la parte demandante identifica la acción ejercitada como reivindicatoria cuando realmente se está ejercitando una acción declarativa de dominio. Ello no tiene en principio importancia pues, como ha determinado la jurisprudencia, el sistema español no es un sistema de acciones, por lo que el nombre dado erróneamente a la acción que se interpone no impide que la adecuada prospere, salvo que la que en realidad se está ejercitando (con nombre erróneo) no cumpla sus propios requisitos". Martínez, Luz M (2013) "Prescripción extintiva de la acción reivindicatoria y adquisición del dominio por usucapión: ¿Dos figuras en liza?”, InDret, Barcelona, p. 5. Disponible en: http://www.indret.com/pdf/979.pdf. [Fecha de visita: 1/12/15]. En igual sentido: Miquel, José María (1979) La Posesión de Bienes Muebles, Madrid, editorial Montecorvo S.A., p. 6.

Este no es un problema menor por cuanto ello dependerá también del auto de prueba. Así la solución española no es aplicable directamente al Derecho chileno. Ello exigiría tener un sistema procesal civil moderno basado en la teoría del caso, que distinga entre demanda, pretensión y acción y que permita al juez reconducir la prueba a la acción pertinente. 
inscrita, viene, hace un buen tiempo ${ }^{14}$, desechando la delimitación clásica entre estas acciones, conforme a la teoría de la posesión inscrita, para extender el ámbito de aplicación de la acción reivindicatoria, y entender a la posesión en los términos del artículo 700 CC, es decir, como $<<$ posesión material $>{ }^{15}$. Los criterios, conforme a los cuales la Corte ha determinado el ámbito de aplicación de las acciones reales, no hacen referencia a problemas en los títulos inscritos en cuyo caso correspondería la acción reivindicatoria, es decir, no aplican la teoría de la posesión inscrita (delimitación clásica). La Corte, en materia de posesión inscrita, se ha alejado de delimitación clásica entre posesión y mera tenencia. Así, la línea jurisprudencial, que se analiza a continuación, recurre lisa y llanamente a dos elementos volitivos y uno objetivo para delimitar la posesión (en caso de operar la teoría de la posesión inscrita), inclinándose en la mayoría de los casos de conflicto a favor de la acción reivindicatoria. Para la Corte los elementos volitivos que determinan la aplicación de la acción reivindicatoria, en desmedro de la acción de demarcación y cerramiento, son el que el actor pretenda la restitución de parte del terreno de un vecino y la defensa del demandado de poseer con ánimo de señor y dueño (es decir, de alegar la detentación material). Ninguno de estos elementos es relevante de acuerdo a la teoría de la posesión inscrita. El elemento objetivo, que lleva a la Corte a desechar la acción de demarcación y cerramiento, e inclinarse por la reivindicación, es el cercamiento unilateral del límite entre los predios por parte del vecino demandado. Conforme a estos tres criterios la Corte estima que lo que procede es la acción reivindicatoria.

Así, se puede consultar a este respecto los siguientes fallos, que son una muestra relevante de esta tendencia.

\section{(2.1.1.) Fallo Corte de Apelaciones de Talca. 5 de abril de 2010. Rol $\mathrm{N}^{\circ}$ 1.286-2009. "Ramírez con Berríos"}

La sentencia precedente desecha una acción de demarcación y cerramiento por estimar que lo demandando era una parte del predio vecino. Lo relevante para el fallo es la ocupación de parte del predio vecino, que el actor intenta le sea restituida. La sentencia decide a favor de la apelación de la demandada contra la sentencia de primera instancia -que aco-

14 En el presente trabajo se analiza la jurisprudencia de la Corte Suprema entre 2010-2015, pero esta línea jurisprudencial viene desde antiguo.

15 La delimitación clásica entre acciones reales está dada conforme a la distinción de si se estamos frente a la posesión material o a una posesión inscrita. Naturalmente que ello determina no solo la diferencia entre el ámbito de competencia de cada acción real, sino también de otras figuras como la tradición o la prescripción adquisitiva. 
gió la demanda de demarcación y cerramiento-; pero sustentando el fallo en que la realidad posesoria, es decir, <<la posesión material $>>$ entre los vecinos, confrontada con los títulos inscritos, llevaba a concluir que había un problema de títulos inscritos. Por esta razón estima que la acción que corresponde es la reivindicatoria y desecha la acción de demarcación y cerramiento. La sentencia resuelve que: "...la actora en su demanda seńala que el demandado ha extendido los límites del terreno que posee hacia su propiedad, corriendo la división, esto es, imputa a su contraparte que con su accionar le ha privado de parte de su propiedad, al estar en posesión de parte de su terreno lo que excede al objeto de una demarcación y cerramiento, siendo más propio de una acción de dominio en los términos del artículo 889 CC, sin perjuicio de observar que del informe pericial que obra en autos la propiedad del demandado aparece con menos superficie de la establecida en su título". Este fallo es destacable por cuanto para él lo esencial es que procede la acción reivindicatoria de existir un problema de tenencia material (que se manifestaría en que un vecino excede los límites de su predio); e indica de una forma tangencial que, de acuerdo al informe de peritos, existiría un problema en los títulos. Así, para el fallo la inscripción no es relevante para resolver si procede la acción reivindicatoria, lo realmente importante es la solicitud de restitución de la tenencia de un paño de terreno.

\section{(2.1.2.) Fallo Corte Suprema. 9 de abril de 2013. Rol No 573-2013. "Inversiones José de Logrońo Limitada con Carvajal"}

Los sentenciadores razonan que la demarcación no importa un desmembramiento de la propiedad, pues al fijarse los límites, que separan predios colindantes, no se hace otra cosa que velar por la integridad de cada predio, estableciendo de un modo preciso la superficie de cada cual y por otra parte, no hay un predio sujeto a otro, sino que todos están recíprocamente en la misma situación. Así, la sentencia, entre muchos supuestos de procedencia de la acción de demarcación y cerramiento -como que se trate de distintos inmuebles que colinden en sus límites; que exista acuerdo entre las partes respecto de los títulos y acerca de sus respectivas calidades de propietarios-, entiende que no deben existir en el terreno cercos, linderos o mojones, que determinen la línea de separación de los predios, ni ninguna forma previa de demarcación. La sentencia acoge el fundamento del actor en virtud del cual acusa al demandado de haber corrido el cerco del deslinde entre las parcelas $\mathrm{N}^{\circ} 24$, de su propiedad, con la parcela $\mathrm{N}^{\circ} 25$, que le permitían ocupar injustificadamente la superficie que señala en su demanda. 
Examinados los antecedentes los jueces concluyen que no se reúnen todos los requisitos de la acción contemplada en el artículo $842 \mathrm{CC}$, por cuanto se tiene por acreditada la existencia de un cerco entre las parcelas ${ }^{16} \mathrm{y}$, además, las partes no están de acuerdo sobre la superficie y forma de sus predios que indicarían sus títulos. En consecuencia, al disponerse la demarcación y cerramiento en tales condiciones, se provocaría una alteración de los mismos predios, lo que excede el ámbito de esta acción ${ }^{17}$.

El fallo resuelve que se adscribe a la jurisprudencia de la $C S$, en orden a que la acción de demarcación procede en la medida que ninguno de los vecinos posea el suelo en cuestión con ánimo de señor y dueño. Y, agrega, que para obtener que se prive a uno de la posesión y se le entregue dicha posesión a otro hay que recurrir necesariamente de reivindicación. Los jueces del fondo concluyen que, encontrándose acreditado en autos que los terrenos del actor y del demandado están materialmente cercados en un deslinde común, la acción de demarcación carece de objeto ${ }^{18}$. Nue-

16 Las sentencias: Corte Suprema. 23 de mayo de 2007. Rol N 3.477-2005. "Arredondo con Palma” y 3 de abril de 2008. Rol N²06-2008. "Olivera con Ferreira", como de las Corte de Rancagua. 31 de octubre de 2006. Rol N 713-2006. "Mella con González” y ValpaRAíso. 7 de mayo de 2008. Rol N²674-2007. "Ramos con Baeza” resuelven en el mismo sentido, exigiendo que no existan linderos que determinen línea de separación para entablar la acción de demarcación y cerramiento.

17 Confrontar con sentencia Corte Suprema. 30 de mayo de 2013. Rol N 7.085-2012, "Silva con Lebtun”, que falla: “...efectivamente, si bien se ha señalado reiteradamente por la doctrina y la jurisprudencia que obstaria a la admisibilidad de la acción que nos ocupa el hecho de solicitarla el propietario de un predio que se encuentre positivamente deslindado, dicha afirmación debe ser entendida a la luz de una adecuada exégesis del artículo 842 del Código de Bello, en términos tales de considerar únicamente como una eficiente excepción a la demanda de demarcación, por carecer ella de objeto, la alegación de existir una delimitación previa, efectuada de común acuerdo por los propietarios interesados o en cumplimiento de una resolución judicial (...).

Sobre el conflicto sub lite, en particular, se ha sostenido que <<no es demostración de que hay deslindes la existencia de un cerramiento, ya que es posible que este-obra exclusiva tal vez de uno solo de los vecinos-ocupe un terreno que no es el de la linea separativa de los fundos contiguos>> (Arturo ALESSANDRI, Manuel SOMARRIVA y Antonio VODANOVIC, "Derecho Civil, Tratado De Los Derechos Reales", Tomo II, Editorial Juridica de Chile, 1993, página 197)" (considerando $6^{\circ}$ ).

$18 \quad$ La CORTE resuelve: "[d]el examen de los antecedentes los jueces concluyen que en la especie no se reúnen todos los requisitos de la acción contemplada en el artículo 842 CC, por cuanto se tiene por acreditada la existencia de un cerco entre las parcelas 24 y 25 y, además, las partes no están de acuerdo sobre la superficie y forma de sus predios que indicarian sus titulos. En consecuencia, al disponerse la demarcación y cerramiento en las condiciones anotadas, expresan los sentenciadores, se provocaría una alteración de los mismos predios, lo que excede el ámbito de esta acción.

Conforme la jurisprudencia de esta CS, en orden a que la acción de demarcación procede si ninguno de los vecinos posee el suelo en cuestión con ánimo de señor y dueño y que, de lo contrario, para obtener que se prive a uno de la posesión y se entregue a otro hay que recurrir necesariamente a la acción reivindicatoria, los jueces del fondo concluyen que encontrándose acreditado en autos que los terrenos del actor y del demandado se encuentran materialmente cercados en un deslinde común, la acción de demarcación carece de objeto, correspondiendo a una acción diversa la petición de la actora" (considerando $5^{\circ}$ ). 
vamente, este fallo deja claro que la detentación es propia de la acción reivindicatoria y jamás de la acción de demarcación y cerramiento.

\section{(2.1.3.) Fallo Corte Suprema. 13 de agosto de 2013. Rol $N^{\circ}$ 6.826- 2012. "Jarpa con Jarpa"}

El presente fallo reitera la jurisprudencia de la $C S$ en virtud de la cual la acción de demarcación y cerramiento solo tendría un alcance declarativo de derechos preexistentes. Así, dicha acción no da lugar a un nuevo título a favor de ninguno de los litigantes, de manera tal que la acción de demarcación y cerramiento resulta desnaturalizada, si se pretende por su intermedio privar al demandado de una porción de terreno de que esté en posesión, a título de señor y dueño ${ }^{19}$. Nótese que solo la última aseveración ignora la teoría de la posesión inscrita, por cuanto entiende a la posesión como detentación, excluyendo cualquier consideración con relación a su aspecto espiritual, es decir, a la inscripción como requisito, garantía y prueba. En concreto, el fallo resuelve que, aunque el demandado posea una superficie más grande de la que expresa su título, el demandante tiene que probar que este exceso de contenido, que forma el objeto determinado de su demanda y que el demandado sostiene haber adquirido por prescripción u otro título, le pertenece. Y, el fallo entiende que, si las partes están en desacuerdo sobre la cabida de sus predios o si una de ellas sostiene haber adquirido la propiedad del suplemento de cabida que presenta su predio, se trata entonces de una verdadera acción reivindicatoria, aunque se haya disfrazado de una petición de demarcación, pues es el derecho de propiedad sobre una parcela determinada el que se encontraría comprometido ${ }^{20}$. El fallo reconoce que ambas acciones exigen la prueba del dominio del actor, pero entiende que la falta de acuerdo en la cabida conlleva a la pérdida de la posesión (al igual que el fallo analizado precedentemente), por lo que desecha la acción de demarcación y cerramiento y se inclina a favor de la reivindicatoria. Una vez más para la sentencia los problemas de tenencia material entre vecinos solo pueden resolverse mediante la acción reivindicatoria.

Estos fallos rehúyen de la teoría de la posesión inscrita para determinar si realmente se ha perdido la posesión. Y sostienen que la posesión se pierde en caso que un vecino detente parte del predio con ánimo de señor y dueño, con total independencia de los títulos inscritos. En resumidas

Ver considerando $13^{\circ}$.

Ver considerando $24^{\circ}$. 
cuentas, en lo relativo a la distinción entre las acciones de demarcación y de reivindicación, para el sentenciador si lo solicitado es la restitución en forma indeterminada de terrenos, que están dentro de los linderos del predio que se pretende demarcar, la acción apropiada es demarcatoria ${ }^{21}$.

\section{(2.1.4.) Fallo Corte Suprema. 17 de marzo de 2014. Rol $N^{\circ}$ 16.816- 2013. "Inmobiliaria Portabello con Navarrete"}

El recurrente sostiene que en la sentencia cuya nulidad persigue, los sentenciadores, al rechazar la demanda se fundaron en que se debieron acreditar unos requisitos inexistentes, que los artículos 842, 844, 889 y 895 CC no contemplan. El actor-recurrente alega que la existencia de un cerco divisorio no obsta a la procedencia de la acción de demarcación y cerramiento, pues lo que se busca es la fijación de los límites entre los terrenos de propiedad de los litigantes. A diferencia de lo que indica la sentencia recurrida de segunda instancia, el hecho que no exista acuerdo entre las partes, sobre dónde debe pasar el deslinde, no implica discusión sobre el dominio, pues no se ha señalado que los demandados hayan invadido ilegítimamente alguna parte del predio de la actora. La parte recurrente alega además que se ha solicitado la restitución de una parte de terreno, pretensión que es propia de una acción reivindicatoria ${ }^{22}$.

21 En igual sentido la sentencia CS. Rol N 7085-2012, resuelve: “...[e]n la reivindicación se pretende tener derecho a una determinada extensión de terreno; en la acción de demarcación no se pretende una extensión de terreno definida, sino que se arguye que los limites resultantes del título o de la posesión son otros que los que afirma la parte contraria. La alteración de los limites existentes no puede perseguirse por la acción de demarcación; es previa la acción reivindicatoria para reclamar los terrenos a que se pretende tener derecho y que posee el vecino: solo una vez reconocido ese derecho procede entablar la acción de demarcación para que se señalen los nuevos limites. Por su parte, la jurisprudencia sobre la materia ha señalado que <<no se desnaturaliza la acción de demarcación incorporando en ella cuestiones de dominio, pues recuperar terrenos -como consecuencia de la fijación justa y legal de los limites que separan a los predios colindantes- es uno de sus fines, siempre que no se los individualice y que su objeto principal sea la fijación de la linea divisoria, con las restituciones consiguientes, pero inciertas en su cantidad y destino. RDJ, Tomo XXXII, segunda parte, sección 1a, p. 183>>” (considerando $7^{\circ}$ ).

$22 \quad$ El fallo resuelve: "...el recurrente sostiene que en el fallo cuya nulidad de fondo persigue han sido conculcados los articulos 842, 844, 889 y 895 CC pues al rechazar la demanda se ha fundado en la inconcurrencia de requisitos que dichas normas no contemplan. Explica que la existencia de un muro o cerco divisorio no obsta a la procedencia de esta acción pues lo que se busca a través de ella es precisamente la fijación de los limites entre los terrenos de propiedad de los litigantes, por no estar claro el lugar donde estos deben ir. A diferencia de lo que indica la sentencia recurrida, el hecho que no exista acuerdo entre las partes sobre donde debe pasar el deslinde no implica la discusión de aspectos del dominio, pues no se ha señalado que los demandados hayan invadido ilegitimamente alguna parte del predio de la actora ni se ha solicitado la restitución de una parte de terreno, pretensiones que son propias de una acción reivindicatoria" (considerando $\left.2^{\circ}\right)$. 
La sentencia de la $C S$ expresa en primer término que para la procedencia de la acción deben concurrir los siguientes tres elementos: la inexistencia de delimitación por medio de vestigios o señales; contigüidad de los predios involucrados y no haber discusión sobre el lugar donde debe correr el confín o deslinde. El fallo señala que no está controvertido que los predios sean colindantes, por lo que enfoca su análisis a la concurrencia de los otros dos elementos. Al respecto, la sentencia agrega que: " $a$ partir de los dos peritajes se concluye que efectivamente se encuentra emplazado un cerco (...), indicando Aliste (...) que estos no abarcan los puntos extremos entre los que se extiende el deslinde. De este modo, constituye un hecho de la causa la existencia de un cerco, aunque los profesionales no son contestes en su longitud"23. Asimismo, el fallo resuelve que la admisión de la pretensión $<<$ sub lite $>>$ presupone la concurrencia de diferentes situaciones fácticas. Entre ellas sería esencial que se interponga por quien es propietario de un predio, que no se encuentre demarcado, ni cerrado materialmente en su deslinde con otra finca, de modo que los inmuebles no sufran alteración, ni se prive al demandado de una porción de suelo que posea a título de seńor y dueño, mediante una condena que lo exhorte a entregar o a restituir al demandante. Según lo razonado, por la sentencia, resulta desnaturalizada la acción contemplada en el artículo $842 \mathrm{CC}$, al afectarse la posesión o el derecho de dominio, cuando se desconoce un deslinde y cierre actualmente existente.

En consecuencia, existiendo una delimitación, que ha sido reconocida por los propietarios de los predios colindantes, cualquier alteración que importe la privación de una porción de terreno, excede la acción de demarcación. En torno a lo que nos interesa, el fallo, sin recurrir a un análisis de los títulos inscritos, entiende que por haber una alteración de los límites entre vecinos -o discusión en torno al cerramiento unilateral de los predios- el problema que se presenta afecta a la posesión y al dominio, y por ende procede la acción reivindicatoria ${ }^{24}$.

El fallo resuelve: “...la sentencia cuestionada que reprodujo y confirmó el fallo de primer grado, rechazando, en definitiva, la demanda expresa en primer término que para la procedencia de la acción deben concurrir tres elementos, cuales son, la inexistencia de delimitación por medio de vestigios o señales, contigüidad de los predios involucrados y no haber discusión sobre el lugar donde debe correr el confín o deslinde. Expresa a continuación que no está controvertido que los predios son colindantes, por lo que enfoca su análisis a la concurrencia de los otros dos elementos. Al respecto, indica que < < partir de los dos peritajes se concluye que efectivamente se encuentra emplazado un cerco (...), indicando Aliste (...) que estos no abarcan los puntos extremos entre los que se extiende el deslinde. De este modo, constituye un hecho de la causa la existencia de un cerco, aunque los profesionales no son contestes en su longitud>>" (considerando $3^{\circ}$ ). 


\section{(2.1.5.) Fallo Corte Suprema. 17 de junio 2014. Rol No 2.422-2013. "Parra con Parra"}

La sentencia precedente es especialmente clara respecto que la acción reivindicatoria tendría como objeto recuperar $<<$ la posesión material $>>$ o $<<$ la detentación de la cosa con ánimo de señor y dueño $>>$. Así, la $C S$ resuelve: “[q]ue, en semejante situación, nuestra jurisprudencia ha sostenido la procedencia de la acción reivindicatoria a favor del dueño y poseedor inscrito de un bien raíz en contra de la persona que detenta la posesión material sobre el mismo, basándose para ello en lo dispuesto por los artículos 889 y 895 del precitado cuerpo legal.

En esta linea jurisprudencial se ha dicho que dentro del sistema instituido por nuestro Código Civil sobre el dominio y posesión inscrita de los bienes raices no cabe duda de que el dueño y poseedor inscrito de un inmueble tiene aptitud juridica para ejercitar la acción reivindicatoria en contra de quien detenta su posesión material' (considerando $19^{\circ}$ ).

De este modo, la CS se inclina a favor de extender la reivindicación a la restitución de la simple detentación con ánimo de señor y dueño, denominada como $<<$ posesión material $>>$. Además, esta sentencia es especialmente interesante por cuanto integra normas constitucionales con civiles $^{25}$, desechando la distinción entre posesión y mera tenencia, en los casos en que el rechazo de la acción haga ilusorio el derecho de propiedad. De este modo, la CS parecería entender que el dominio privado de la detentación, simplemente transforma al dueño en nudo propietario.

minio, cuando se desconoce un deslinde y cierre actualmente existente. En efecto, existiendo una delimitación que ha sido reconocida por los propietarios de los predios colindantes, cualquier alteración a la misma, que importe la privación de una porción de terreno, excede la acción de demarcación, resultando por ello acertada la consideración de los jueces de la instancia, en cuanto rechazaron la demanda de autos, tras haber asentado la circunstancia de existir cierres en el deslinde que separan los predios de las partes, situación fáctica que resulta inamovible para esta Corte, al haber sido establecida por los sentenciadores del mérito en uso de las facultades que les son privativas sin que se halla impugnado el fallo denunciando infracción a leyes reguladoras de la prueba" (considerando $5^{\circ}$ ) (lo destacado en cursiva es mío).

25 La CoRTe resolvió: “... [c]oncluida, por ende, esta vía procesal, no le restaba a la demandante otra opción que acudir al principal instrumento juridico que nuestro sistema normativo pone a disposición del dueño de una cosa singular para asegurar el pleno dominio sobre la misma: la acción reivindicatoria. De otra manera, quedaria la demandante desprovista de todo medio de defensa juridica respecto de un derecho que, como el de propiedad, se encuentra expresamente elevado a la condición de garantía fundamental, asegurada en el artículo $19 N^{\circ} 24$ de la Constitución Politica de la República". 


\section{(2.1.6.) Fallo Corte Suprema. 24 de junio de 2014. Rol No 178-2014. "Montiel con Báez"}

Este fallo sostiene que la acción de cerramiento y demarcación tiene por objeto únicamente que se fijen los límites o deslindes, que separan el predio de quien ejerce la acción de los inmuebles colindantes, tanto de un modo jurídico, es decir, orientado a reconocer la línea divisoria, como de una manera material, esto es, a través de la instalación de los hitos apropiados. Para la CS en la acción de demarcación y cerramiento no puede existir discusión acerca de la cabida de los predios vecinos, pues, en ese evento, muta la pretensión hacia una acción diversa. Los requisitos que hacen procedente esta acción corresponden a la presencia de predios distintos, la vecindad entre ellos y que las partes concuerden en sus cabidas y títulos.

La CS estima que el fallo impugnado, al exceder el marco del ejercicio de la acción intentada por la actora, infringe el artículo 842 CC, por falsa interpretación, extendiéndose la aplicación de dicha norma a dilucidar una cuestión de dominio, por lo que acoge la casación opuesta por el demandado ${ }^{26}$.

La sentencia fue acordada con dos votos en contra, que pusieron en evidencia el conflicto de la posición mayoritaria con la teoría de la posesión inscrita. Los votos de minoría estuvieron por rechazar el recurso por no haberse excedido el marco de la acción intentada, ya que esta se concede no solo para el evento de que se trate de instalar cercos cuya ubicación no sea discutida, sino también para el evento de modificar los cierros y reinstalarlos en el lugar que corresponde. En opinión de los disidentes -que se adscriben claramente a la teoría clásica de la posesión inscrita-, la pretensión que supone alterar los hitos, que se reubicaron equivocadamente, no importa la reivindicación de una porción de terreno determinado y preciso. Ello se debe a que el ejercicio de la acción de demarcación y cerramiento, como señala Alessandri, puede conducir a una restitución de terreno, respecto de una porción de terreno indefinida y desconocida y la propiedad no necesita ser acreditada a priori y como requisito de procedencia de la demarcación ${ }^{27}$.

\footnotetext{
26 Ver considerandos $6^{\circ}$ a $9^{\circ}$.

27 El Ministro Aránguiz y el abogado integrante Peralta estuvieron por rechazar el presente recurso de casación (voto disidente), por no haberse excedido el marco de la acción intentada, ya que esta se concede no solo para el evento de la instalación de cercos cuya ubicación no sea discutida, sino también para una eventual modificación de los cierros, reinstalados en lugar distinto. En opinión de los disidentes la pretensión, que supone alterar los hitos que se reubicaron equivocadamente, no importa la reivindicación de una porción de terreno determinado, ya que del ejercicio de la acción en examen puede resultar una restitución de terreno, indefinido y desconocido, por cuanto su propiedad no necesita ser acreditada a priori, como requisito de la acción de demarcación.
} 


\section{(2.1.7.) Fallo Corte de Apelaciones de Valdivia. 5 de octubre de 2015. Rol No 968-2015. "Collado con Gallego"}

La sentencia precedentemente individualizada desechó la tesis tradicional, respecto de la teoría de la posesión inscrita, para entender que el demandado de reivindicación es poseedor, basándose en aspectos fácticos, de lo que otros fallos han denominado como <<posesión material $>>$. Ello se desprende claramente del fallo, que resuelve: “...[e]xplica que ocupa el inmueble desde el año 2000 debido a una compraventa de derechos sucesorios que hizo a uno de los herederos de la sucesión de Gonzalo (...), además de arrendamientos de predios colindantes, lo que por desconocimiento nunca se escrituró ni se cumplieron con las solemnidades, realizando actos de conservación, cuidados y mejoras del inmueble, ostentando un título que es la prescripción adquisitiva extraordinaria, por haberlo ocupado sin violencia ni clandestinidad por más de diez años" (considerando $1^{\circ}$ ) y "[c]onforme a lo

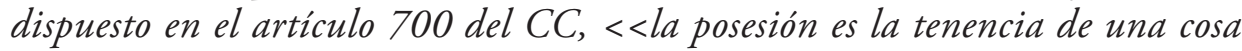
determinada con ánimo de señor y dueño... >>, lo que importa la existencia de un ánimo o voluntad que debe ser exteriorizada en actos materiales; ante ello, debe tenerse en consideración que en el Informe Pericial agregado a fojas 123 y siguientes, no objetado, se constató que el demandado ha realizado en el terreno labores de limpieza y ha construido edificaciones, los que corresponden a actos propios de quien se reputa poseedor. Asi resulta de lo dispuesto en el artículo 925 CC, en cuanto expresa que la posesión del suelo se prueba por hechos positivos de aquellos a los que solo da derecho el dominio como construcción de edificios u otros de igual significación, ejecutados sin el consentimiento del que disputa la posesión, como justamente ha acontecido en este caso.

Con esos antecedentes queda establecido que el demandado ha ejercido posesión sobre el terreno que es del dominio de los demandantes, por lo que es procedente acoger la acción reivindicatoria ejercitada" (considerando $2^{\circ}$ ). El fallo agrega, en el mismo considerando, que la posesión, a pesar que el actor ha invocado la posesión inscrita, se puede acreditar mediante la prueba de testigos. La sentencia entonces admite la prueba de testigos contra título inscrito y de este modo da por acreditada la calidad de poseedor del demandado ${ }^{28}$. La actora indica en su demanda que es poseedora inscrita,

28 El fallo resuelve: "[q]ue en lo concerniente a la calidad que el demandado se atribuye, de ser un mero detentador del inmueble, deberá tenerse en consideración que sus propios testigos, declarando a fojas (...) expusieron en forma reiterada que Juan (...) es poseedor del inmueble. Asi lo declararon los testigos Rodrigo (...), Raúl (...) y Miguel (...)”. La sentencia de primera instancia en sus vistos resuelve, respecto del libelo, que: "...es poseedor irregular de dicho predio el demandado Juan (...), quien ocupa el inmueble, sin tener titulo alguno que respalde su ocupación de 
a pesar de acompañar una única inscripción, aspecto que es corregido durante el juicio al acompańarse las inscripciones anteriores -que una en pos de las otras acreditan el dominio por cubrir el plazo de prescripción adquisitiva-.

En definitiva, el sentenciador resolvió concede la acción reivindicatoria en contra de un detentador, sin necesidad de recurrir a la figura del artículo 915 CC (injusto detentador).

\section{(2.1.8.) Conclusiones parciales}

a) Los tribunales vienen desplazando la acción de demarcación y cerramiento, a favor de la acción reivindicatoria. Los fallos precedentes constituyen una clara línea jurisprudencial que exige que concurran las siguientes dos condiciones para que la acción de demarcación y cerramiento prospere: a) los predios no sufran de alteración alguna, ni se prive al demandado de una porción de suelo, que posea a título de señor y dueño, el cual deba entregar o restituir al demandante; y b) ninguno de los vecinos posea el suelo con ánimo de señor y dueño ${ }^{29-30}$. Es de destacar que ambos requisitos son contrarios a la

la propiedad, causando graves problemas y perjuicios a sus representados". Sentencia de 7/5/15, del Juzgado de Letras y Garantía de Panguipulli, Rol N C-248-2013. Obtener información de sitio web Poder Judicial en http://civil.poderjudicial.cl/CIVILPORWEB/, introduciendo en: Rol: "C -248-2013", y en tribunal: "Juzgado de Letras y Garantía de Panguipulli" [Fecha de visita: 2/12/2015].

29 La sentencia, Corte Suprema. 24 de junio de 2014. Rol № 178-2014. "Montiel con Báez", falla: "[q]ue, en relación con la acción de cerramiento y demarcación, reiteradamente se ha sostenido que tiene por objeto únicamente que se fijen los limites o deslindes que separan el predio de quien ejerce la acción de los inmuebles colindantes, realizándose tal fijación tanto de un modo jurídico, es decir, orientado a reconocer la línea divisoria, como de una manera material, esto es, a través de la instalación de los hitos apropiados. En otros términos, no puede existir discusión acerca de la cabida de los predios vecinos, pues, en ese evento, muta la pretensión hacia acciones diversas, sea posesorias o reivindicatorias..." (considerando $5^{\circ}$ ). En igual sentido, la CA de Valparaíso resolvió: “...[e]s indispensable, entonces, que la acción se deduzca por quien es propietario de un predio, el que no se encuentra demarcado ni materialmente cerrado en su deslinde con otro predio, por lo que los predios no sufren alteración, ni se priva al demandado de una porción de suelo que posea a título de señor y dueño el cual deba entregar $o$ restituir al demandante" (considerando $5^{\circ}$ ) y "...procede la acción de demarcación si ninguno de los vecinos posee el suelo con ánimo de señor y dueño...” (considerando $7^{\circ}$ ). CA de Valparaíso 24/09/09, Rol No 2747-2007. Disponible en: www.westlaw.cl CL/ JUR/1661/2009 [Fecha de visita: 29/11/15].

30 Como se ha señalado esta línea jurisprudencial de la CS no es reciente. Ver sentencia de la Corte Suprema. 1 de diciembre de 2004. Rol N².819-2003. "Inversiones Gora Limitada con Maturana Vargas, Mónica y otros”. El fallo precedente resuelve que: “...algo muy distinto acontece en la acción reivindicatoria, en que una de las partes pretende ser propietario de una parte del predio contiguo, o bien en que cada uno de los litigantes reclama un trazado para la línea de separación de los predios y la controversia se suscita sobre la determinación misma de los límites. Se tratará, entonces, de una verdadera acción reivindicatoria, aunque se la haya disfrazado de una petición de demarcación, pues es el derecho de 
teoría de la posesión inscrita por cuanto atienden a los elementos constitutivos de lo que podría denominar como posesión material, es decir, al $<<$ corpus $>>$ y al $<<$ animus $>>$. La teoría de la posesión inscrita solamente desecha la acción de demarcación y cerramiento -independientemente que un vecino haya cercado unilateralmente su predio $^{31}$ - en caso que existan problemas en los títulos inscritos con relación a la cabida de los predios. Ello se debe fundamentalmente a que solo en estos casos se generará un genuino problema de posesión entre vecinos, que conduce a que la acción reivindicatoria desplace a la acción de demarcación y cerramiento.

b) Estos fallos sostienen una tesis voluntarista de la posesión, por cuanto estiman que la sola discusión respecto de los límites de los predios vecinos conlleva un problema de posesión, es decir, de reivindicación, y jamás de delimitación entre los predios, o sea de demarcación y cerramiento. $Y$, en realidad, lo que declaren las partes en juicio es funcional a sus intereses, por lo que la calificación jurídica de las partes no debería ser vinculante para el tribunal, como si una parte denomina arrendamiento a una compraventa, o señala que hay un problema de posesión, donde existe un problema de tenencia material, etcétera.

c) El fallo de la CS. Rol N 2.422-2013 es especialmente interesante por cuanto establece una de las máximas que hemos podido observar

propiedad sobre una porción de terreno el que se encontraría comprometido en el proceso" (considerando $7^{\circ}$ ), y “...esta Corte ha resuelto de la misma manera, esto es, que la finalidad de la acción de demarcación es fijar los límites que separan a dos predios colindantes y supone que no existen en el terreno linderos o señales que determinen su línea de separación y que estos no han sido antes demarcados, pues de lo contrario se encubriría una acción de dominio (sentencia de cinco de mayo de 1998, causa del Tercer Juzgado Civil de La Serena, publicada en la Revista de Derecho y Jurisprudencia, tomo XCV, sección 1, página 31). Del mismo modo lo ha hecho en causa Rol 1682-03, por sentencia de diecisiete de mayo de 2004 , en que sostuvo que si por la acción de demarcación se pretende privar a la demandada de la posesión de parte del inmueble y entregarla al actor, debe recurrirse obligatoriamente a la acción reivindicatoria. Por último, en causa Rol 2075-03 de este tribunal, por sentencia de 26 de agosto pasado (publicada en La Semana Jurídica No 206, página 7), ha reiterado el mismo principio al sostener que si el predio ya estaba totalmente demarcado con el del vecino, las diferencias existentes entre las partes no pueden ser solucionadas mediante una acción de demarcación y cerramiento, puesto que en verdad se refieren al dominio y posesión de una franja de terreno, materias que deberían ser objeto de acciones de naturaleza diferente" (considerando $8^{\circ}$ ).

31 A este respecto es muy conocida la posición de Alessandri R., Somarriva y Vodanovic. Para dichos autores - conforme a una jurisprudencia anterior a la que estamos analizandola $C S$ entendía que no es contraria a la acción de demarcación la discusión de aspectos sobre el dominio, toda vez que eventualmente puede implicar una recuperación de terrenos debido a la nueva fijación del límite de los predios. Ello siempre que en las peticiones no se haya individualizado dichos terrenos, y que la pretensión principal sea la fijación de la línea divisoria. Incluso se señala que dicha acción no era incompatible con el cercamiento unilateral de su predio por parte de un vecino. Alessandri (2005) 196. 
en otras sentencias, como lo es que la acción reivindicatoria cubriría supuestos, en que otras acciones reales no protegen al dueño.

\section{(2.2.) REVERSIÓN DE LA TENDENCIA DEL DESPLAZAMIENTO DE LA ACCIÓN REIVINDICATORIA POR LA ACCIÓN DE SIMPLE PRECARIO}

En los fallos precedentes se puede apreciar como la $C S$ recurre a consideraciones que se alejan de la lógica de los bienes, y amplía el ámbito de aplicación de la acción reivindicatoria. Así, se puede apreciar como consistentemente la jurisprudencia de la $C S$ ha optado por extender la acción reivindicatoria a supuestos de mera tenencia a través de una reinterpretación del artículo $915 \mathrm{CC}^{32}$, y asienta la tendencia a preferir la acción reivindicatoria sobre el resto de las acciones reales ${ }^{33}$. Junto a esta tendencia también hay que recalcar que la $C S$-en cuanto al ámbito de la acción de precario los criterios de exclusión de los contratos que no son oponibles al dueño, es decir, que no llevan a enervar su mera tolerancia o ignorancia-, recurre a la teoría de los bienes.

\section{(2.2.1.) Fallo Corte Suprema. 1 de septiembre de 2010. Rol No 7.219- 2008. "Tallar con Benzanilla"}

La sentencia precedente resolvió que procede la acción reivindicatoria contra el denominado injusto detentador (artículo 915 CC). La CoRTE hace años comenzó a desechar la interpretación clásica de la referida norma, que entendía que ella solo hacía que al injusto detentador se le apliquen las reglas de las prestaciones mutuas, y que jamás procedía la ac-

32 Estas sentencias son interesantes por cuanto tradicionalmente se ha sostenido que, en la medida que se busque poner fin a la detentación de la cosa por parte de un tercero, la acción de precario no tiene grandes diferencias con la acción reivindicatoria. Así, se ha entendido que las diferencias entre ambas acciones son prácticas. La primera diferencia está dada por la rapidez del procedimiento, propio del precario, con la lentitud del procedimiento ordinario respecto de la reivindicatoria. La segunda consiste en las ventajas que ofrecen las prestaciones mutuas, en la acción reivindicatoria, y las escasas reglas restitutorias del precario. La tercera diferencia estaría dada por la prueba del dominio, que en el precario es menos exigente, que en la acción reivindicatoria.

33 La extensión de la acción reivindicatoria a supuestos de acción de precario ha sido una respuesta a un fenómeno natural entre nosotros que ha sido dado por la preferencia forense por la referida acción. Nuestra doctrina hace años que ha puesto de relieve que, en el diseño de Bello, la acción de precario era una figura excepcional y totalmente marginal con relación a la acción reivindicatoria.

Domínguez, Ramón (1992) "Comentario jurisprudencia. Precario. Comodato precario. Conveniencia. Prueba del dominio", Revista de Derecho de la Universidad de Concepción $\mathrm{N}^{\circ}$ 192, ańo XL, julio-diciembre, pp. 211-213. 
ción reivindicatoria en su contra ${ }^{34}$. Así, el fallo precedente resuelve, que: “...para la procedencia de la acción reivindicatoria del citado artículo 915, deberá establecerse si lo hace de manera indebida o bien porque está amparado en un título que lo habilita para ello" (considerando $5^{\circ}$ ). Específicamente la sentencia concede la acción real contra un comunero, que habría transgredido los derechos de los otros copropietarios ${ }^{35}$.

\section{(2.2.2.) Fallo Corte Suprema. 19 de diciembre de 2012. Rol No 6.860- 2011. "Oliver con Molina" y Corte de Apelaciones de San Miguel. 25 de junio de 2014. Rol No 214-2014. "Lara con Aránquiz"}

La sentencia precedente extiende un contrato de comodato al cónyuge del comodatario precario. Así, la CS estima que, aun cuando la demandada no tiene la calidad de parte en el comodato, dicha convención le sirve como título de tenencia, porque el motivo que lo indujo a su celebración era que el predio sirviera de vivienda no solo al comodatario, sino que también a su familia (cónyuge e hijos) ${ }^{36}$. En un fallo similar la $C A$ de San Miguel, de 25/6/14, resolvió que la ocupación de la conviviente con la que se tuvo dos hijas y una relación de más de diez años impediría que la acción de simple precario prospere. Ello se debería, en razón de la CoRTE, a que la ocupación no fue por mera tolerancia del dueño. Pero, como destaca el voto de minoría, en realidad la ocupación posterior al término de la convivencia precisamente se debe a la mera tolerancia del dueño.

34 En consideración a esta posición se sostenía que para que la acción reivindicatoria procediera contra el injusto detentador, el artículo 915 debería estar ubicado en el párrafo $3^{\circ}$, que regula $<<$ contra quien se puede reivindicar $>>$, y no en el párrafo $4^{\circ}$ de las prestaciones mutuas. Además, se sostenía que el tenor literal del artículo al referirse a las "reglas de este título", hace alusión a las prestaciones mutuas. Rozas, Fernando (2004) Los Bienes, Tercera edición, Santiago de Chile: LexisNexis, p. 375.

35 El fallo precedente agrega que: “...en lo que respecta a la alegación de haber obrado el demandado como un comunero, dentro del marco legal que rige la comunidad, sin reclamo de los demás, al haber arrendado a terceros un terreno de 600 metros cuadrados, que equivale a un porcentaje menor a sus derechos, y que, por tanto, seria de su propiedad, cabe reiterar que el fallo de primera instancia, confirmado por la sentencia recurrida, estableció como hecho, lo contrario, esto es, que el demandado, Ricardo (...), ocupa el retazo de terreno de propiedad del demandante, en el cual instaló unas antenas transmisoras, y que dio en arriendo a terceros" (considerando $8^{\circ}$ ).

36 La demandada alegó que el actor otorgó al marido de la demandada, quien además es hijo de aquel, un préstamo de uso sobre el inmueble sub lite, para que este se asentara y desarrollara su grupo familiar formado por el matrimonio del comodatario y la demandada. Así, habitaban la vivienda la demandada y una hija de esta, nieta del actor, por más de treinta años.

La sentencia de primera instancia desechó la demanda. La actora apeló y la $C A$ de Antofagasta, mediante fallo de 21 de agosto de 2009, revocó, accediendo al libelo. 
Por otra parte, la posición de la CoRTe es discutible por cuanto no señala una categoría jurídica para mantener la tenencia del bien, como podría haber sido la comunidad de vida o los alimentos ${ }^{37}$.

\section{(2.2.3.) Fallo Corte Suprema. 15 de enero de 2014. Rol No 13.741- 2013. "Inversiones e Inmobiliaria Carla con Servicios Gráficos" y Corte de Apelaciones de San Miguel. 10 de agosto de 2011. Rol No 455-2011. "Moraga con Inmobiliaria Ltda."}

La vinculación entre acción real y personal en el simple precario ha sido resuelta adecuadamente por los tribunales. Así, una nutrida línea jurisprudencial desecha la oposición de contratos personales, que no le empecen o no le son oponibles al dueńo. En este sentido, se puede consultar la sentencia de la CS. Rol No 13.741-2013, por la que se desecha como título que sea oponible al simple precario un contrato de arrendamiento sobre el bien objeto del litigio, que fue suscrito por un tercero, por cuanto dicho contrato solo obliga a las partes que lo suscriben ${ }^{38}$. Sin perjuicio de lo cual, se ha considerado que los actos celebrados por los dueños, que anteceden en la propiedad del actor, le son oponibles al demandante ${ }^{39}$. A este respecto, también se puede consultar el fallo de la $C A$ de San Miguel, 10/8/11, Rol No 455-2011.

37 La sentencia, de segunda instancia, resolvió: “...en cuanto al tercero y último, es un hecho pacifico, no discutido, cuestionado ni controvertido, sino que ratificado por los asertos de los testigos que declaran en la causa, señores (...) ; y especialmente por la confesional prestada por ambos litigantes (...), que entre ellos existió una relación afectiva de convivencia por más de 10 años, producto de la cual nacieron sus hijas" (considerando $6^{\circ}$ ) y "...en opinión mayoritaria de esta Corte, lo referido conduce a necesariamente a concluir, que en la situación sub lite existió y existe entre las partes un vinculo o relación de familia, con los consecuentes derechos y obligaciones que de él derivan. Lo que impide considerar la tenencia por la demandada del bien raiz cuya restitución se reclama, meramente sufrida, tolerada o ignorada, sin fundamento alguno, apoyo o titulo de relevancia juridica por el demandante. Menos si en dicho inmueble habitan junto a su madre las hijas de los contendientes, respecto de quienes también se solicita la desocupación de aquel" (considerando $8^{\circ}$ ).

38 Sentencia del 5० JLC de Santiago, Rol N² 21.501-2011.

39 Ver: sentencia Corte Suprema. 28 de enero de 2014. Rol No 12.256-2013. "Puga con Contreras", que rechaza un recurso de casación en el fondo interpuesto por el actor, señalando que la tenencia del demandado perfectamente puede derivar de propietarios anteriores, con relación al domino del actor. 


\section{(2.2.4.) Fallo Corte Suprema. 19 de marzo de 2015. Rol No 10.619- 2014. "Polanco con Saavedra"}

La sentencia confirma un fallo conforme al cual la reivindicatoria es la acción contra el <<poseedor material >> demandado, en lugar del simple precario. El caso es algo más complejo, ya que otro juicio entre las mismas partes -en dicho procedimiento el mismo actor obtuvo un fallo ejecutoriado a su favor, por la que se acogió su acción reivindicatoria-, fue declarado abandonado. El primer juicio comenzó con una demanda reivindicatoria, que fue acogida por sentencia definitiva de primera instancia, de 9 de enero de 2001. Dicho fallo fue revocado por la $C A$ de Chillán por resolución de fecha 25 de junio de 2002, que rechazó la demanda. La CS, conociendo del recurso de casación en el fondo, mediante fallo de 21 de julio de 2003, invalidó de oficio. Y la sentencia de reemplazo confirmó el fallo de primera instancia que acogió la demanda, dando lugar a la reivindicación. Finalmente, en el cumplimiento del fallo, por resolución ejecutoriada de 23 de marzo de 2009, se declaró el abandono del procedimiento. Ante el abandono del procedimiento, el mismo actor demandó de simple precario a los mismos demandados.

En lo que acá interesa, este segundo juicio (CS. Rol No 10.6192014), acogió un recurso de casación en el fondo contra la sentencia de segunda instancia, que resolvió a favor del actor, dando lugar al precario. Es así, como se aprecia que los fallos que conceden ambas acciones (reivindicatoria, primero y precario después), fueron corregidos por la $C S$, al estimar que procede la reivindicatoria y no la acción de precario. La sentencia del máximo tribunal es consistente en asentar que, aún conforme al régimen de posesión inscrita, puede haber $<<$ posesión material $>>$. Así, la CS resuelve que: "...en concordancia con lo reflexionado, cabe concluir que tanto la discusión planteada en el juicio de reivindicación como lo decidido por sentencia ejecutoriada recaida en el mismo, obsta al instituto en estudio, toda vez que la tenencia material de los demandados respecto del inmueble singularizado en el libelo pretensor, no reconoce dominio ajeno sino ánimo de obrar como señor y dueño, lo que hace inconcurrente la necesaria condición que debe ir unida a la ausencia de título, cual es, la ignorancia o mera tolerancia del dueño" (parte considerando $\left.19^{\circ}\right)^{40}$.

En resumidas cuentas, el fallo de la $C S$ es consistente con lo resuelto en el primer juicio, por el cual entiende que la posesión se pierde por la

Ver considerandos $10^{\circ}$ y $18^{\circ}$. 
detentación con ánimo de señor y dueño, independientemente que no exista título inscrito respecto de dicha detentación.

\section{(2.2.5.) Fallo Corte Suprema. 6 de julio de 2015. Rol № 25.669-2014. "Olivares con Olivares"}

La sentencia precedente se pronuncia en los autos Rol $N^{\circ} 7.114-$ 2011, seguidos ante el Segundo Juzgado Civil de Rancagua. La demanda se presenta por curadores conjuntos y definitivos en contra de un hijo de un interdicto por demencia, Miguel (...), y de una sociedad constituida por este para que restituya los bienes del demente. El actor, sujeto a interdicción desde el año 2004 cuando tenía 85 años, presenta sus facultades mentales seriamente deterioradas, lo que llevó a dos de sus hijos a solicitar su interdicción por demencia, que les fue concedida mediante sentencia de 9 de marzo de 2009. Dicha interdicción fue confirmada por la $C A$ de Rancagua, designándose como curadores definitivos a los actores, y excluyéndose expresamente al demandado. Los demandados el año 2005, encontrándose el actor con Alzheimer, habrían incorporado los bienes que se reivindican a la sociedad demandada.

En definitiva, se acoge la acción reivindicatoria contra el demandado, considerándolo como injusto detentador, ya que se habría apropiado de los bienes del demente, aprovechándose de su incapacidad ${ }^{41}$.

\section{(2.2.6.) Conclusiones parciales}

a) Las sentencias precedentes nos permiten comprobar como se ha extendido el ámbito de la acción reivindicatoria a expensas de la de simple precario. El fallo de la CS. Rol No 13.741-2013, es claro a este respecto cuando considera que de perder el dueño $<<$ la posesión material $>>$ procede la acción reivindicatoria y desecha la acción de precario (considerando $10^{\circ}$ ). Otros fallos se inclinan a favor de la acción reivindicatoria, pero esta vez recurriendo a la figura del injusto detentador (fallos CS, Rol N $\mathrm{N}^{\circ}$ 7.219-2008. "Tallar con Benzanilla” y CS. Rol $N^{\circ} 25.669-2014^{42}$ ). Lo que no resuelve bien la CS, en estos supuestos, es la exclusión de la acción de precario, a manos de la

Ver considerandos $3^{\circ}$ a $6^{\circ}$.

Ver: Barrientos, Javier (2007) "De los Bienes y de su Dominio, Posesión, Uso y Goce: Poseedor a Nombre Ajeno", Revista Chilena de Derecho Privado Nº 8, pp. 273-280; PÉrez, María Francisca (2014) "La protección del dueño ante quien retiene indebidamente un bien. Análisis jurisprudencial del artículo 915 del Código de Bello", RDUCN, Volumen 21, No 1, pp. 387-421 y Selman, Arturo (2011) "Artículo 915 del CC: una solución jurisprudencial a la limitación de las acciones tradicionales", Ius et Praxis, Año 17, No 1, pp. 57 
acción reivindicatoria, cuando por cualquier motivo el dueño opta por aquella. En la causa Rol No 10.619-2014, la razón por la que se excluye la acción de precario consiste en tener los demandados la posesión material del retazo de terreno (considerando $10^{\circ}$ ), y por el ánimo que concurre en ellos. El demandado tiene "ánimo de obrar como señor y dueño" (considerando $19^{\circ}$ ), supuesto que, de acuerdo al sentenciador, excluye la acción de precario. Así, la sentencia también resuelve que no concurriría, dada la referida posesión con ánimo de señor y dueño, la mera tolerancia o ignorancia del dueño, propia del precario (considerando $18^{\circ}$ ). En definitiva, la CS desecha el que exista un posible ámbito común entre estas acciones. No se desecha la acción de precario, porque haya cosa juzgada (supuesto que acontecería si tuvieran un ámbito de aplicación común), sino porque son acciones diferentes.

b) Sin perjuicio de lo anterior, el fallo precedente realiza una diferenciación entre ambas acciones que no es del todo clara. Ello, por cuanto en la medida que el demandado detente la cosa con ánimo de señor y dueño, procedería la reivindicación, y si lo hace por ignorancia o tolerancia del dueño, la de precario. Como es evidente podría darse el supuesto de detentación con ánimo de señor y dueño, por parte del demandado, y por ignorancia o tolerancia del dueńo, por parte del actor. En dicho caso al parecer procedería la reivindicatoria por cuanto dicha acción tendría un contenido subsidiario a la falta de acción.

c) Los fallos de la CS. Rol No 6.860-2011, y de la CA de San Miguel, Rol No 214-2014, excluyen la acción de precario dando lugar a una concepción controversial, como evidencia el voto de minoría (en el segundo fallo), de tolerancia o ignorancia del dueño. El fallo de la $C S$ protege a la cónyuge del comodatario, extendiendo el ámbito del contrato a la familia de la comodataria, en perjuicio del actor, dueńo del inmueble y abuelo de una de las hijas de la demandada. La protección es formal, ya que se indica que el contrato se extendería a la familia de la comodataria y del propio comodante. En cambio, el fallo de la CA de San Miguel va más lejos y entiende que la ocupación de una conviviente, con la que se tuvo dos hijas el demandante, excluye $<<$ per se > la acción de precario. Este razonamiento naturalmente está implícito en el fallo de la CS, que se cuida de no explicitar. Ello se debe a que en el idioma de los bienes este razonamiento es inconcebible, por cuanto supone un paso previo consistente en la justificación de la pérdida de la posesión, e incluso del dominio, en

- 80. La poca recepción de estas teorías en la jurisprudencia no les hace justicia a los excelentes trabajos precedentes. 
razón de la protección de la familia. Este es un aspecto importante por cuanto acá se aprecia una aplicación extensiva del derecho de alimentos y la declaración de bien familiar ${ }^{43}$.

\section{(2.3.) ÁMBITO PREFERENTE DE LA ACCIÓN DE SANEAMIENTO: ¿UN DOMINIO PREFERENTE?}

El sistema articulado por el $D L \mathrm{~N}^{\circ} 2.695$, que fija normas para regularizar la posesión de la pequeńa propiedad raíz y para la constitución del dominio sobre ella, corrige alguno de los problemas que genera la teoría de la posesión inscrita al preferir la posesión material sobre aquella. De este modo, el $D L \mathrm{~N}^{\circ} 2.695$ vuelve al concepto de posesión en los término que lo hace el artículo $700 \mathrm{CC}$, desplazando a la teoría de la posesión inscrita. Para el $D L$, la posesión se configura por la concurrencia del $<<$ corpus $>>$ y del $<<$ animus $>>$, a lo que se suma la pasividad del poseedor inscrito, entre otros requisitos ${ }^{44}$.

El poseedor inscrito y eventual dueño tiene dos instancias para oponerse al procedimiento de saneamiento:

a) El poseedor inscrito y eventual dueño, como un tercero -una vez que el Servicio notifica la solicitud, mediante carta certificada, al supuesto propietario del inmueble, identificando el terreno, comprobados los requisitos del artículo 2 del $D L \mathrm{~N}^{\circ} 2.695$, conforme al artículo $10.4^{\circ}$ del mismo cuerpo normativo, y efectuadas las publicaciones, que exige el artículo 11 del $D L \mathrm{~N}^{\circ} 2.695-{ }^{45}$, podrá oponerse ante el Servicio (artículo $20.2^{\circ}$ y $3^{\circ}$ del $D L{ }^{46}$. Este procedimiento de oposición se rige por el PÁRRAFo $2^{\circ}$ DEL Título IV (artículos 26 y 27 del $D L)$.

b) El dueño puede entablar una acción reivindicatoria dentro del plazo de un año, contado desde la fecha de la inscripción del inmueble,

43 No se puede dejar de lado que estos derechos se sustentan en deberes propios de la familia, pero su aplicación debería ser restrictiva por cuanto afectan al dominio. Precisamente por ello el ordenamiento jurídico exige la concurrencia de ciertas condiciones para declarar un usufructo sobre inmueble, como derecho de alimentos, o declarar un bien como familiar. En un juicio de alimentos, el abuelo puede defenderse haciendo valer su situación económica, como justificación para no conceder un usufructo a favor de sus nietos. Una discusión de esta clase no se da en el ámbito de aplicación de una acción real. El Derecho de cosas es sordo frente a estas consideraciones, por ello es que la argumentación de la $C A$, no es correcta. Y por ello es que la $C S$ se cuida de no recurrir a dicho razonamiento.

44 El saneamiento procede aún contra título inscrito (artículo $2.2^{\circ} \mathrm{del} D L$ ).

45 El poseedor inscrito, además de este medio, podrá enterarse del saneamiento por la anotación marginal que deberá hacerse al margen de su inscripción (artículo 15.3 del $D L$ ).

46 La oposición del tercero está contemplada en el artículo $11.3^{\circ}$ del $D L$, y debe producirse dentro de los 30 días hábiles contados desde la publicación del último aviso. De no producirse la oposición se ordenará realizar la inscripción a nombre del solicitante. 
que se produce dentro del procedimiento de saneamiento y que le concede la calidad de poseedor regular al solicitante.

A continuación se analizarán los alcances de la declaración de dominio del $D L$, respecto de las inscripciones que se cancelan, y su relación con la posesión material.

\section{(2.3.1.) Fallo Corte Suprema. 20 de noviembre de 2013. Rol $\mathrm{N}^{\circ}$ 7.528-12. "Banco de Chile con Villanueva"}

El Banco de Chile, Rol No 40.655-2009, seguido ante el Juzgado de Letras de Bulnes, dedujo una demanda de reivindicación en contra de Juan (...) que había obtenido una inscripción de saneamiento, alegando que ello vulneraba su derecho de propiedad. El Banco de Chile señaló que había adquirido el bien raíz, denominado San José (....), mediante una adjudicación en juicio ejecutivo contra el anterior propietario Renán $(\ldots)^{47}$.

La CS, conociendo de un recurso de casación en el fondo, interpuesto por la demandada anuló el fallo de alzada. Así, la sentencia de la Corte Surema. Rol No 7.528-12 resuelto el fallo anulatorio, dicta inmediatamente y de forma separada la respectiva sentencia de reemplazo. La sentencia de reemplazo, de la CS resuelve: "[q]ue como se ha visto, el demandado adquirió la calidad de poseedor regular del bien raiz sublite el dia 22 de julio de 2007 y la demanda reivindicatoria de lo principal de fojas 7, le fue notificada legalmente el 22 de septiembre de 2009. En consecuencia, se debe concluir que la acción de dominio intentada en autos, no tuvo la virtud de interrumpir civilmente el término que la ley establece para ejercerla y, por lo mismo, se extinguió por la prescripción" (considerando $5^{\circ}$ ). De este modo, la $C S$ resuelve que la reivindicatoria se había interpuesto después del año y por tanto la propiedad ya había sido adquirida conforme al $D L$. A su vez, el sustento normativo del fallo está en su considerando $2^{\circ}$ por el cual la Corte considera que el $<<q u i d>>$ del asunto está en la aplicación del artículo $16.1^{\circ}$ y $2^{\circ}$ del $D L 2.695$, por el cual se dispone que "[c] omo consecuencia de lo dispuesto en el artículo precedente, expirado el plazo de un año a que esa disposición se refiere, prescribirán las acciones emanadas de los derechos reales de dominio, usufructo, uso o habita-

47 La sentencia de primera instancia desechó la demanda, pero la CA de Chillan acogió el libelo en todas sus partes, resolviendo una apelación y una casación en la forma interpuesta por la demandante. 
ción, servidumbres activas y el de hipotecas relativos al inmueble inscrito de acuerdo con la presente ley.

Las anteriores inscripciones de dominio sobre el inmueble, asi como la de los otros derechos reales mencionados, las de los gravámenes y prohibiciones que lo afectaban, una vez transcurrido el citado plazo de un año, se entenderán canceladas por el solo ministerio de la ley, sin que por ello recobren su vigencia las inscripciones que antecedian a las que se cancelan" 48 (la cursiva es mía).

La pregunta evidente, que no aborda la CorTe, es: ¡a qué acciones se refiere el inciso primero de la norma precedentemente citada, cuando establece: "...prescribirán las acciones emanadas de los derechos reales de dominio, usufructo, uso o habitación, servidumbres activas y el de hipotecas relativos al inmueble inscrito de acuerdo con la presente ley"? Y la respuesta naturalmente es que dicha disposición solo puede referirse a los derechos que emanan de las inscripciones anteriores a la solicitud de que se trata, es decir, anteriores a la inscripción de la demandada que es de 22 de junio del 2007, y no a las posteriores (la inscripción de la actora es de 29 de octubre del 2007). Por lo que se puede entender que la demandante, al estar de buena fe habría adquirido por prescripción ordinaria de cinco años, poniendo fin al dominio a que dio lugar el saneamiento. Ello se debe a que la inscripción de adjudicación del demandante, es decir, del BANCO De Chile, es de 29 de octubre del 2007, y la inscripción del decreto de saneamiento es de 22 de junio [o julio] del mismo año. Por tanto la discusión que acá se generaba es entre un dominio adquirido, conforme a las reglas del saneamiento de la pequeña propiedad, y una inscripción posterior, obtenida por el demandante -que la llevaría a adquirir por prescripción adquisitiva-, y que pone fin a la inscripción anterior, es decir, a la que declaraba el saneamiento.

En resumen, este fallo establece una suerte de saneamiento del dominio inexpugnable, que no se ve afectado por una prescripción adquisitiva posterior. En consideración a ello, en principio, la acción de prescripción adquisitiva no tendría destino contra un dominio saneado por las reglas del $D L$. Ello contradice la preferencia de la detentación material de la

$48 \quad$ El referido considerando establece que: “... [s]egún lo previene el artículo 16 del referido decreto ley, una vez que ha expirado el indicado plazo prescriben las acciones que emanan de los derechos reales de dominio, usufructo, uso o habitación, servidumbres activas y de hipotecas relativos al inmueble que se inscribió de acuerdo a las disposiciones del DL No 2695. Esta norma no es sino la aplicación de la regla de carácter general que se contiene en el artículo 2517 CC, en cuanto dispone que toda acción por la cual se reclama un derecho, se extingue por la prescripción adquisitiva del mismo derecho". 
cosa planteada por la Corte respecto del ámbito de aplicación de algunas acciones reales.

\section{(2.3.2.) Fallo Corte de Apelaciones de Santiago. 14 de octubre de 2014. Rol No 8.401-2013. "Valdera con Novoa"}

Esta sentencia es complementaria a la precedente. El fallo de la $C A$ de Santiago, anteriormente individualizado da un giro a la sentencia precedente. Para la Corte el procedimiento de saneamiento afecta todas las inscripciones, que deriven de las directamente canceladas, alcanzando aún al poseedor material ${ }^{49}$. De esta forma, el dominio saneado por el DL podría ser afectado eventualmente por el Derecho común, pero jamás respecto a cualquier posesión inscrita que derive de los títulos cancelados.

En la referida causa, la demandante Adelina (...) -después de obtener inscripción registral de la propiedad a su nombre con fecha 20 de noviembre de 1990, mediante procedimiento de regularización de la posesión de la propiedad del $D L-$ interpone una acción reivindicatoria contra Laura (...), y sus causahabientes. Como se desprende del considerando tercero del fallo Adriana (...), adquirió la propiedad en disputa por herencia de Jorge (...), mediante inscripción de fojas (...) del Registro de Propiedad del CBR de Santiago del año 1957. A su vez, por resolución judicial de 15 de diciembre de 1993, inscrita a fojas (...) del Registro de Propiedad del año 1994, se concedió la posesión efectiva de la herencia intestada quedada al fallecimiento de Adriana (...) a la cesionaria de los derechos hereditarios, Laura (...), quien obtuvo inscripción especial de herencia del inmueble a fojas 39.602, $\mathrm{N}^{\circ} 25.928$ del Registro de Propiedad del $C B R$ de Santiago del año 1994. Por escritura pública de 26 de febrero de 2004 Laura (...) vendió el inmueble precedentemente individualizado a Gladys (...), quien lo inscribió a su nombre a fojas (...) del Registro de Propiedad del CBR de Santiago, correspondiente al año 2004. El 16 de marzo del mismo año 2004 Gladys (...) vendió la referida propiedad a Eduardo (...), quien lo inscribió a su nombre a fojas (...) del Registro de Propiedad del $C B R$ de Santiago de ese año ${ }^{50}$. En torno a lo que interesa, se produce un conflicto entre dos inscripciones. Una proviene del procedimiento de saneamiento, respecto de la cual el sentenciador indica que se desprendería el dominio, y la otra de las inscripciones can-

\footnotetext{
49 Ver artículo $16.2^{\circ}$ del $D L \mathrm{~N}^{\circ} 2.695$.

50 Es de destacar que esta última contaba con una sentencia de precario contra la actora, ya que por sentencia judicial recaída en autos Rol N ${ }^{\circ} 4.227-2001$, ante el $27^{\circ} J L C$ de Santiago, Laura (...) obtuvo sentencia de restitución contra Adelina (...), por acción de precario.
} 
celadas en virtud del mismo procedimiento de saneamiento (considerando $\left.6^{\circ}\right)^{51}$. La $C A$, en definitiva, se inclina a favor del saneamiento, y en contra de las inscripciones que derivan del título nulo ${ }^{52}$; y la sentencia se sustenta exclusivamente en los artículos 15 y 16 del $D L^{53}$.

El fallo precedentemente es criticable por cuanto el artículo 16 del $D L$ solo concede al solicitante la calidad de dueño, y consecuentemente cancela las inscripciones anteriores; pero en virtud del saneamiento el solicitante no recibe un dominio preferente, que no pueda verse afectado por la prescripción adquisitiva. No parece entonces que esté justificado que haya un dominio preferente, aunque se circunscriba a los títulos inscritos o posesión que derive de títulos cancelados en conformidad al referido artículo $16^{54}$.

\section{(2.3.3.) Fallo Corte Suprema. 22 de enero de 2014. Rol $N^{\circ}$ 6.553- 2013. "Forestal Tierra Chilena Ltda., con Aguilar Vidal María Lugardina y otros"}

La $C S$, en algunas ocasiones, ha revisado el procedimiento a través del cual se obtuvo la declaración de saneamiento, aun después de vencido el plazo para entablar la respectiva acción reivindicatoria. Así, la sentencia precedentemente indicada confirma un fallo de segunda instancia, que declara la nulidad absoluta de la inscripción por objeto ilícito. La nulidad se funda en falta de posesión material del predio y la presentación de un título en la causa Rol $N^{\circ} 20.593$, sobre reivindicación, en la que las demandadas eran demandantes, y en el cual se desechó su libelo ${ }^{55}$. De

51 La sentencia resuelve: “...en lo que atañe, enseguida, a la exigencia de ser la actora dueña de la cosa que reivindica, es menester reflexionar que conforme se advierte del mérito de la prueba documental allegada al proceso, especialmente inscripciones registrales a nombre de las partes (...), se aprecia que respecto del inmueble de calle (...) existen materialmente dos inscripciones de dominio que amparan a titulares distintos: por una parte, la de 20 de noviembre de 1990, a nombre de la demandante y, por otro, la de 19 de marzo de 2004, a nombre del demandado. La solución del litigio pasa, en consecuencia, por determinar cuál de las dos inscripciones ha de prevalecer, de manera tal que su titular será el propietario exclusivo y excluyente del bien raiz sobre que versa, definiendo en definitiva tal conclusión el éxito o el fracaso de la presente acción".

52 El fallo de segunda instancia resolvió que el inmueble de calle (...) es de dominio exclusivo de Adelina (...) y condenó al demandado a restituir a la actora el bien raíz reivindicado.

53 Ver considerandos $5^{\circ}$ a $10^{\circ}$.

54 El fallo no se pronuncia sobre si el actor, eventualmente poseedor inscrito y material, podría adquirir por prescripción adquisitiva contra un dominio saneado por el $D L$, en la medida que dicha posesión no derive de títulos cancelados en virtud del $D L$.

55 La CS desecha un recurso de casación en la forma y el fondo, interpuesto por la demandada, contra la sentencia dictada de la $C A$ de Concepción por la que, a pesar que desecha el fallo de primera instancia, rechaza la apelación interpuesta contra el $2^{\circ}$ Juzgado Civil, Rol $\mathrm{N}^{\circ}$ 6.553-2013. El fallo de segunda instancia revoca la sentencia impugnada por apelación, 
este modo, la $C S$ acoge la nulidad del procedimiento de saneamiento por cuanto el solicitante jamás había sido poseedor material, es decir, revisa que los requisitos que exige la ley para sacar un bien del patrimonio de una persona, e incorporarlo al de otra a través de la prescripción adquisitiva cumpla efectivamente con las condiciones que exige el $D L \mathrm{~N}^{\circ} 2.695$.

\section{(2.3.4.) Fallo Corte Suprema. 30 de enero de 2014. Rol No 1.1246 - 2013. "Lozano con Quezada"}

En esta causa, al igual que la causa anterior, la demandante interpone una acción reivindicatoria, basada en que era dueńa de la cosa sobre la que la demandada obtuvo una declaración fraudulenta de saneamiento por falta de posesión material. La demandante obtuvo sentencia favorable tanto en primera $\left(2^{\circ} J L C \text { de Curicó }\right)^{56}$, como en segunda instancia ( $C A$ de Talca $)^{57}$. Interpuestos los respectivos recursos contra la última sentencia, la $C S$ confirmó el fallo recurrido, rechazando los recursos de casación en la forma y el fondo, interpuesto por la demandada. En cuanto a lo que nos interesa, el fallo desecha el recurso de casación en el fondo, debido a que la recurrente: "omitió extender la infracción legal a las normas que tienen el carácter de decisorias de la litis, en el caso de autos, las relativas a la reivindicación o acción de dominio, no obstante que en sus planteamientos ha insistido en que se debe modificar el fallo por cuanto se encuentra acreditado que el actor no es el dueño de los terrenos que actualmente se encuentran en posesión de la parte demandada por haberse extinguido el derecho de este por prescripción, situación fáctica, que lleva a concluir que necesariamente pro-

que acogía la demanda declarando una nulidad de derecho público. Sin embargo, acoge los planteamientos subsidiarios de la demanda, los que también son acogidos por la CS.

El demandante sustenta su pretensión en ser dueña de una propiedad raíz. La demandada se defendió aduciendo haber sido poseedora de buena fe por aproximadamente veinte ańos. El fallo resuelve que la posesión de la demandada sobre el bien raíz en discusión es "un hecho indiscutible". Asimismo, falla que en razón de la prueba rendida, la misma cumplió con el trámite administrativo contemplado en el $D L$ 2.695, que permite adquirir la posesión de los bienes que contempla dicho estatuto. Con todo, agrega que la resolución emanada del antedicho trámite "no sirve de base absoluta y definitiva" para suponer que la posesión fue ejercida de buena fe, sino que tal circunstancia es una cuestión de hecho, y como tal debe ser acreditada, o refutada en juicio. En la especie, fue posible determinar que lo contrario es lo correcto, es decir, que hubo mala fe, pues la demandada regularizó e inscribió un bien raíz que ocupaba por mera tolerancia del dueño original, bien que a la sazón pasó a la sucesión y finalmente al demandante. Se concluye, entonces, que la resolución administrativa no sanea el, o los, vicios que en su constitución pueda haber adolecido la posesión. De este modo, y atendida todas las piezas probatorias el tribunal decide acceder a la pretensión reivindicatoria de la demandante.

57 No es del caso referirse a los recursos de casación contra la última sentencia, por cuanto la CS confirmó el fallo recurrido, rechazando los recursos de casación en la forma y el fondo, interpuesto por la demandada. CS. Rol N 11.246-2013. 
cede rechazar la demanda interpuesta en estos autos" (considerando $7^{\circ}$ ). El rechazo del recurso se funda en la trasgresión de las normas que regulan las reglas de la casación. Por ello, en realidad, la $C S$ no analiza lo que la recurrente alega que es que la sentencia recurrida no prefirió las normas del $D L$ sobre las comunes, al no declarar la prescripción adquisitiva de sus derechos, y la extinción de los derechos de la demandante, conforme al artículo 16 del $D L^{58}$.

\section{(2.3.5.) Conclusiones parciales}

a) Las sentencias precedentes suelen otorgar unos efectos radicales a la inscripción de saneamiento, conforme al artículo 16, en desmedro de las inscripciones registrales que derivan de las canceladas (CS. Rol $\mathrm{N}^{\circ}$ 7.528-12 y CA. Rol No 8.401-2013).

b) Los referidos fallos otorgan un alcance al artículo $16.2^{\circ}$ del $D L 2.695$ que no parece del todo justificado. Las sentencias precedentes rechazan las demandas contra la inscripción saneada, conforme a dicho procedimiento, que se basan en una posesión que se mantiene en el tiempo, es decir, que va más allá del saneamiento, pero que tiene un origen anterior al referido saneamiento. Ello es más que discutible por cuanto la inscripción de saneamiento, que da origen al dominio, si no es impugnada mediante acción reivindicatoria transcurrido -en el plazo de un año desde la declaración por el ente administrativo de la posesión regular-, no impide que un tercero pueda adquirir la posesión en el intertanto, aunque ella derive de una inscripción cancelada por efecto del saneamiento. Los títulos nulos son simplemente injustos títulos y dan lugar a la posesión irregular por aplicación del artículo $704.1^{\circ}, \mathrm{n}^{\circ} 3 \mathrm{CC}$. Así, la posesión puede alcanzarse conforme a las teorías de la posesión inscrita - de derivar su inscripción de una inscripción cancelada conforme al procedimiento de saneamiento- o de la posesión material (posición reciente de la $C S$ ). Y dicha posesión

58 La CS, en otros fallos, como Corte Suprema. 4 de marzo de 2014. Rol No 15.896-2013, "Morgado Saldivia Verónica con Vergara González Claudia Carol", sostuvo lo contrario. El fallo desecha un recurso de casación en el fondo interpuesto por la parte que se opone al saneamiento por aspectos formales. Así, el fallo de la $C S$ desecha lo alegado por la recurrente en cuanto a que: "los sentenciadores desestiman la prueba aportada por la comunidad demandante puesto que los documentos aportados son posteriores a la época en que se presentó la solicitud de regularización ante el Ministerio de Bienes Nacionales por la demandada. Por todo lo anterior, es que rechazan la oposición que se ha formulado por cuanto la solicitante logró acreditar los presupuestos fácticos exigidos por los artículos 2, 3 y 4 del Decreto Ley $N^{\circ} 2695$ " (considerando $3^{\circ}$ ), y ello se debe a que "la recurrente no denunció, de modo eficiente, la vulneración de las normas reguladoras de la prueba, lo que habría permitido, una vez constatada tal infracción, analizar las probanzas de autos $y$, en su caso, modificar los hechos establecidos por los sentenciadores" (considerando $4^{\circ}$ ). 
puede llevar a la prescripción adquisitiva ordinaria o extraordinaria, conforme a las reglas generales.

c) Las sentencia de la CS. Rol N6.553-2013 y 1.246-2013 anulan la sentencia de saneamiento, y su respectiva inscripción, por fraude a la ley que se sustenta en la omisión de la posesión material. Estos últimos fallos son complementarios porque, aunque no van contra la teoría de la posesión inscrita, integran dicha teoría dentro del concepto de posesión del artículo 700 CC.

\section{(2.4.) DETERMINACIÓN DE LA CONCURRENCIA DE LAS QUERELLAS DE AMPARO Y RESTITUCIÓN}

La diferencia entre las querellas de amparo y restitución está claramente delimitada conforme a la teoría de la posesión inscrita. De este modo se ha entendido que si se pierde la tenencia del bien, el dueño o poseedor no pierde la posesión de estar esta protegida por una inscripción. Por tanto, en dicho supuesto, lo que procedería sería la acción de amparo. Así se desprendería del artículo 921 CC, por el que, de mantenerse la posesión y perderse la tenencia material del inmueble, se estaría turbando o embarazando la posesión. Para que proceda entonces la acción de restitución, que tiene por objetivo poner fin al despojo de la posesión, conforme a la teoría de la posesión inscrita debe haberse obtenido la cancelación de la inscripción ${ }^{59}$.

Así, Alessandri y Somarriva señalan como supuesto de aplicación de la querella de amparo, las publicaciones en el diario para inscribir un inmueble, por parte de un tercero, respecto del que tiene una inscripción vigente. Nótese que en este caso no se cancela la inscripción porque de obtenerse una inscripción, aunque no se cancele una anterior, entonces sí se podría entablar la querella de restitución por cuanto se habría perdido la posesión. Alessandri Arturo y Somarriva, Manuel (1940) Tratado de los Sujetos y de los Objetos del Derecho, Tomo II, Santiago de Chile, Editorial Nascimento, p. 677. En forma todavía más nítida Claro Solar señalaba que: "[d]entro de las disposiciones de nuestro Código que han establecido para la adquisición de la posesión de bienes raíces, en virtud de títulos translaticios de dominio, la inscripción en el $C B R$ y con arreglo a las cuales la posesión inscrita no se pierde, sino cuando la inscripción se cancela, sea por la voluntad de las partes, sea por una nueva inscripción en que el poseedor inscrito transfiere su derecho a otro, o por decreto judicial (hay nota al pie); el poseedor inscrito a quien se arrebate el predio, o se le impida entrar en él, no será efectivamente despojado de su posesión, si el usurpador no tiene título inscrito sobre el mismo inmueble, que le permita prescribir su dominio (art. 2505); pero será perturbado en su posesión por esos actos que le embarazan o impiden el ejercicio de la posesión que conserva sobre el inmueble". Claro Solar, Luis (1992) Explicaciones de Derecho Civil Chileno y Comparado, Volumen IV: De los Bienes, Tomo Octavo: De los Bienes, IV, Santiago de Chile, Editorial Jurídica de Chile (imprenta Nascimento, Santiago, Chile, 1935), pp. 516-517. En igual sentido se puede consultar a Peñailillo. Peñailillo, Daniel (1997) Los Bienes, Santiago de Chile, Editorial Jurídica de Chile, tercera edición, p. 392. 
Esta es la solución que nos ofrece la teoría de la posesión inscrita en torno al ámbito de aplicación de las referidas querellas. Pues bien, como consecuencia de la asimilación de la posesión -aún respecto de la posesión inscrita- a la posesión material esta solución se ve radicalmente alterada.

\section{(2.4.1.) Fallo Corte de Apelaciones de Rancagua. 31 de diciembre de 2010. Rol No 915-2010. "Agrícola y Ganadera con Cruz"}

En esta causa el actor entabla una querella de restitución o de despojo violento, por la cual pide el retiro de postes y tendido eléctrico emplazados irregularmente en su predio, solicitándose además volver las cosas al estado anterior en que se encontraban. La $C A$, analizando los artículos 926 y 927 CC, estimó que la acción material de levantar postes y tendido eléctrico, aunque afecta parcialmente la posesión, no puede dar lugar a una restitución. Por ello, la sentencia da lugar al recurso de apelación, interpuesto por la demandada, y revoca el fallo de primera instancia, de 23/8/10, que acogía la acción ${ }^{60}$. Así, la $C A$ resuelve que: “...lo que está en juego en los hechos planteados es la perturbación parcial de la posesión que sin cuestionamiento goza el demandante, sin que exista dato alguno respecto a que ello haya ocurrido mediante violencia $\mathrm{u}$ otro acto malicioso que permita determinar, indubitadamente, la pérdida de dicha posesión en los términos en que la acción electa lo exige" y "en consecuencia, la acción en la forma que ha sido planteada, no puede ser acogida, y ello sin perjuicio del ejercicio de otras acciones; por lo que al resolver lo contrario la Jueza del grado, obliga a esta CORTE a revocar la sentencia en alzada, para asi declararlo" (considerandos $4^{\circ}$ y $5^{\circ}$ ).

\section{(2.4.2.) Fallo Corte Suprema. 25 de junio de 2013. Rol № 7.116- 2012. "Sociedad Pigmentos Naturales con Guagama"}

La sentencia precedente resuelve que si se considera que la tenencia material es uno de los elementos constitutivos de la posesión, es dable concluir que el poseedor inscrito que se ve privado de ella sufre, al menos, un despojo parcial de su posesión, que le impide o menoscaba el ejercicio de la misma y lo habilita para exigir la restitución. Y el fallo agrega que la $C S$ ha sostenido que "...una concepción tan estricta de esta norma-instituida a propósito de la adquisición de la posesión de los bienes raices- contraría la intención de

Ver considerando $3^{\circ}$. 
la protección posesoria consagrada por el legislador (se refiere a la pérdida de la posesión conforme a la teoría de la posesión inscrita), en cuanto importa privar al poseedor inscrito que pierde la tenencia material del bien raiz del derecho que le otorga el artículo 921, para defender su posesión y pedir, sea que no se turbe o embarace su ejercicio, sea que no se le despoje de ella. Si se considera que la tenencia material de la cosa es uno de los elementos constitutivos de la posesión, es dable concluir que el poseedor inscrito que se ve privado de ella sufre, al menos, un despojo parcial de su posesión que le impide o menoscaba el ejercicio de la misma y lo habilita para exigir la restitución" (lo señalado entre paréntesis es mío $)^{61}$. Este fallo es interesante porque, aunque se refiere a la querella de restitución, señala claramente que la teoría de la posesión inscrita no puede desconocer los alcances que la jurisprudencia de la CORTE le otorga a $<<$ la posesión material >>, y comprende que un acto de detentación de la cosa afecta y despoja parcialmente de la posesión. Ello como se planteó al comienzo de este acápite iría contra la teoría de la posesión inscrita, que en casos de pérdida de la tenencia material concede la querella de amparo.

\section{(2.4.3.) Fallo Corte Suprema. 30 de abril de 2014. Rol No 13.721 - 2013. "Pizarro con Vergara"}

La sentencia anterior ha resuelto que para la procedencia de los interdictos en análisis se requiere, entre otros, haber demostrado la posesión actual y la amenaza, perturbación y/o el despojo, total o parcial. Lo anterior importa que para que se promuevan estas querellas -que persiguen el amparo y la restitución de la posesión- se debe, inexcusablemente, acreditar una posesión anterior; que ha sucedido la perturbación o el despojo por actividad del ocupante demandado; y que la acción se ha ejercido dentro de los términos legales ${ }^{62}$. Así, se ha entendido que es posible enta-

$61 \quad$ El fallo recurrido resuelve que: "se ha discutido en doctrina si el poseedor inscrito que ha sido privado materialmente de su predio puede recurrir a la querella de restitución para recuperarlo, dado que conforme al artículo 728 del mismo cuerpo normativo, el simple apoderamiento de la cosa por un tercero no produce la pérdida de la posesión inscrita y, por ende, no podría configurar un despojo, sino a lo sumo, perturbación o embarazo en el ejercicio de la misma. (...)

Esta CS ha admitido esta doctrina y aceptado la admisibilidad de la acción posesoria de restitución cuando el poseedor inscrito se encuentra en la situación del querellante. Así, analizando el alcance del artículo 926, ha sostenido que "es procedente dentro de la ley, el ejercicio de la acción posesoria prevista en el citado artículo 926 CC por cuanto siendo el demandante poseedor inscrito ha perdido la tenencia material de sus predios, o sea, se le ha privado de uno de los elementos constitutivos de la posesión, que ahora, por medio de esta acción, pretende recuperar" (considerando $5^{\circ}$ ). Corte Suprema. 21 de septiembre de 1955. RDJ, Tomo LII, p. 294.

$62 \quad$ El fallo de la CS, resuelve: “...A este respecto, resulta necesario precisar que para la procedencia de los interdictos en análisis se requiere, entre otros, haber demostrado la posesión actual y la amenaza, perturbación y/o el despojo, total o parcial. 
blar ambas acciones de forma conjunta, lo que es bastante discutible, ya sea que se acoja o no la teoría de la posesión inscrita o de la mentada teoría de la posesión material.

\section{(2.4.4.) Conclusiones parciales}

Las Cortes de Apelaciones aún aplican la teoría de la posesión inscrita; pero la Corte Suprema, como se desprende de los últimos dos fallos, considera la pérdida de la detentación o posesión material como una forma de pérdida parcial de la posesión, aun de haber inscripción conservatoria. Ello tendría como consecuencia que, en estos casos, la querella de restitución desplazaría a la querella de amparo.

\section{3) CONCLUSIONES}

1) La posesión, entendida como un concepto ideal que solo puede adquirirse, conservarse o perderse conforme a una inscripción conservatoria, ha sido puesta en entredicho por la jurisprudencia, a lo menos respecto a la concurrencia de acciones reales.

2) La CS respecto de la concurrencia de acciones ha dado prevalencia a una concepción netamente voluntarista de la posesión, que ha desplazado la teoría de la posesión inscrita. Ello naturalmente ha aparejado una confusión en el foro que ha llevado a que en muchos casos las acciones reales sean desechadas por preferirse una acción real sobre otra.

3) En una primera etapa los fallos de la $C S$ desechan que la inscripción por sí sola dé lugar a la posesión. La posesión, aun en los casos de haber inscripción, se constituye conforme al artículo 700 CC, es decir, exige $<<$ corpus $>$ y $<<$ animus $>$ > Por ello, aunque se tenga una inscripción conservatoria, los derechos del que tenga la inscripción a su nombre no prosperarán contra el poseedor material. Así por lo demás se ha resuelto respecto de las denominadas inscripciones de papel $-\mathrm{o}$ sea aquellas inscripciones que no obedecen a una realidad posesoria-. A ello ahora se suma la interpretación sostenida por la CORTE en torno al artículo $16.2^{\circ}$ del $D L$ 2.695, que ha llevado a anular las inscripciones obtenidas en un proceso de saneamiento en los casos en que el solicitante jamás ha tenido el $<<$ corpus $>>$ y el $<<$ animus $>>$. En este sentido la referida línea jurispru-

Lo anterior importa que para que se promuevan estas querellas que persiguen el amparo y la restitución de la posesión se debe, inexcusablemente, acreditar una posesión anterior; que ha sucedido la perturbación o el despojo por actividad del ocupante demandado; y que la acción se ha ejercido dentro de los términos legales" (considerado $28^{\circ}$ ). 
dencial no es contraria a la delimitación clásica en torno a la diferenciación entre la posesión y la mera tenencia.

4) Lo realmente novedoso de la jurisprudencia analizada respecto de la concurrencia de acciones, es el esfuerzo de la $C S$ por extender los alcances de la acción reivindicatoria en desmedro de otras acciones reales, como las de demarcación y cerramiento y precario. La posesión, entendida como un concepto ideal, ya no se ve complementada por la posesión entendida como $<<$ posesión material $>>-$ como en los casos precedentes-, sino se ve definitivamente desplazada por esta. De este modo, tenemos que la acción de demarcación y cerramiento, de fijarse unilateralmente un deslinde por un vecino, es prácticamente improcedente. En la medida que se afecte la detentación de parte del predio vecino, independientemente que haya superposición de inscripciones, procede únicamente la acción reivindicatoria. El esfuerzo de la CS es loable por cuanto naturalmente la reivindicatoria vuelve a ser la acción real más importante, y ello es encomiable por cuanto ella no es solo una acción restitutoria, sino que permite, a través de las prestaciones mutuas, resolver de mucho mejor manera los conflictos en relación a lo que se deban recíprocamente las partes en torno a frutos, mejoras, perjuicios, etcétera. La CoRTE además distingue entre ambas acciones en relación al ánimo de señor y dueño, que se desprende de la simple detentación, que sería lo que determina que la acción procedente sea la reivindicatoria y que en su concepto excluye la ignorancia o tolerancia del verdadero dueño.

5) La CS entiende que la inscripción, a que da lugar el saneamiento de la pequeña propiedad, es prácticamente inexpugnable no solo respecto de las inscripciones que preceden al título saneado, sino que también respecto de las que deriven de él ${ }^{63}$. Una vez efectuada la inscripción, que da lugar a la calidad de poseedor regular y transcurrido un año, solo se admite la impugnación del dominio por una especie de fraude a la ley <<ad initio $>>$ por falta de posesión material. Pero curiosamente no admite que el dominio adquirido por medio del $D L \mathrm{~N}^{\circ} 2.695$, posteriormente, sea adquirido por prescripción adquisitiva por parte de un poseedor, que sea material y/o que tenga una inscripción, que derive de una de las inscripciones canceladas.

6) La tendencia jurisprudencial, que ha evidenciado el presente trabajo -que consiste en exigir que la posesión, aunque sea inscrita, obedezca a una realidad posesoria-, también tiene efectos sobre lo que se entiende como embarazo y despojo de la posesión, en las querella posesorias, por cuanto se considera que la afectación de la <<posesión material >> no es un acto de embarazo, sino derechamente un acto de despojo. Por ello, este supuesto

63 El primer supuesto no es más que la aplicación del artículo $16.2^{\circ}$ del $D L$, pero el segundo es novedoso. 
que, conforme a la teoría de la posesión inscrita, da lugar a la querella de amparo, ahora se ve protegido por la acción de restitución.

7) Sin perjuicio de los esfuerzos de la $C S$, la tesis del desplazamiento de la teoría de la posesión inscrita por la mera detentación con ánimo de señor y dueño no está debidamente justificada en las sentencias analizadas y no se hace cargo de las normas que entienden a la inscripción conservatoria como una forma de garantía de la posesión sobre cosa corporal inmueble (artículos $728.2^{\circ}, 730.2^{\circ}$ y 2505 CC). Además, los fallos de la CS solo aparentemente están sustentados en justicia material, como se demuestra en los casos de pluralidad de acciones reales rechazadas. Es así como esta tesis afecta la estabilidad del dominio, que es protegida por una teoría de la posesión y mera tenencia que no está debidamente justificada por la $C S$, y la eficacia del Derecho privado.

8) Esta jurisprudencia ha generado una gran confusión y exceso de litigación, como se ha podido apreciar de las sentencias de casación de la CoRte Suprema. La CS, como se aprecia del presente trabajo, continuamente ha corregido a CoRTes de Apelaciones, que suelen aplicar la teoría de la posesión inscrita.

\section{BIBLIOGRAFÍA}

Alessandri R., Fernando (1999) Partición de Bienes, Santiago de Chile: Editorial Jurídica Conosur Ltda.

Alessandri R., Arturo; Somarriva U., Manuel; Vodanovic H, Antonio (2005) Tratado de los Derechos Reales, volumen II, Sexta Edición. Santiago, Chile. Editorial Jurídica.

Alessandri R., Arturo y Somarriva U., Manuel (1940) Tratado de los Sujetos y de los Objetos del Derecho, Tomo II, Santiago, Chile, Editorial Nascimento.

Alessandri R., Arturo, Somarriva U., Manuel, y Vodanovic H., Antonio (1993) Derecho Civil, Tratado De los Derechos Reales, Tomo II, Santiago, Chile: Editorial Jurídica.

Atria Lemaitre, Fernando (2005) "Derechos reales", Revista de Derecho de la Universidad Adolfo Ibáñez, número 2: 2005. Comentario de la jurisprudencia del año 2004, Legis, Peñalolén y Viña del Mar, pp. 70-76.

, (2010) "La tierra para el que la trabaja", en BArros, FigueroA y TAPIA (coordinadores). Estudios de Derecho Civil VI, Jornadas Nacionales de Derecho Civil, Olmué, Abeledo Perrot, Legal Publishing Chile, Santiago de Chile, 2011, pp. 229-236. 
Barcia Lehmann, Rodrigo (2010) Código Civil. Doctrina y Jurisprudencia, Cuatro tomos, Thomson-Reuter Puntolex, Santiago de Chile.

Barrientos, Javier (2007) "De los Bienes y de su Dominio, Posesión, Uso y Goce: Poseedor a Nombre Ajeno", Revista Chilena de Derecho Privado $\mathrm{N}^{\circ}$ 8, pp. 273-280.

Belmar, Eduardo (1948) "Sobre utilidad sobre la posesión viciosa", Revista de Derecho y Jurisprudencia, tomo 45, Primera parte, pp. 2736.

Claro Solar, Luis (1992) Explicaciones de Derecho Civil Chileno y Comparado, Volúmenes IV y V: De los Bienes, Santiago de Chile: Editorial Jurídica de Chile (1935) Tomo Octavo y Noveno: De los Bienes, Santiago, Chile: Imprenta Nascimento.

Domínguez Águila, Ramón (1992) "Comentario jurisprudencia. Precario. Comodato precario. Conveniencia. Prueba del dominio", Revista de Derecho $\mathrm{N}^{\circ}$ 192, año XL, julio-diciembre, U de Concepción.

Fuentes Olmos, Jessica (1998) El Derecho de Propiedad en la Constitución y la Jurisprudencia, Santiago de Chile, Editorial Jurídica ConoSur Ltda.

Herrera Reyes, Luis (1960) "Sobre la teoría de la posesión en el Derecho Romano. La llamada propiedad bonitaria", Revista de Derecho Universidad de Concepción, No 113, Año XXVII/julioseptiembre.

Herrera Robles, Aleksey (2003) "Límites constitucionales y legales al derecho de dominio en Colombia, Análisis desde el Derecho Público", Revista de Derecho, Universidad del Norte, $\mathrm{N}^{\circ} 20$, Barranquilla, Colombia, pp. 57-81.

Larroucau Torres, Jorge (2014) "La 'prueba completa' del dominio en la acción reivindicatoria", en Estudios de Derecho Civil IX, en Turner y Varas (coordinadores) Santiago de Chile, Thomson Reuters, pp. 103-123.

Larroucau, Jorge y Rostión, Ignacio (2013) "Del juicio de precario", Fundamento de Derechos Reales en el Derecho Chileno, BARCia (Coordinador y editor científico), Santiago: Thomson Reuters.

Lathrop, Fabiola (2011) "Procedencia de la acción meramente declarativa del dominio en el derecho chileno", Ius et Praxis, Año 17, No 2, pp. 3-24.

Martínez Velencoso, Luz M. (2013) "Prescripción extintiva de la acción reivindicatoria y adquisición del dominio por usucapión: ¿Dos figuras en liza?”, InDret, Barcelona, abril, pp. 1-29.

Miquel González, José María (1979) La Posesión de bienes muebles (estudio del artículo 464, 1, del CC), editorial Montecorvo SA, Madrid, España. 
Mosquera Ruiz, Mario y Maturana Miquel, Cristián (2010) Los recursos procesales, segunda edición actualizada, Santiago, Chile: Editorial Jurídica.

Peñailillo Arévalo, Daniel (1997) Los Bienes, tercera edición. Santiago, Chile: Editorial Jurídica.

Pérez Peña, María Francisca (2014) "La protección del dueño ante quien retiene indebidamente un bien. Análisis jurisprudencial del artículo 915 del Código de Bello", RDUCN, Volumen 21, No 1, pp. $387-421$.

Rozas Vial, Fernando (2004) Los Bienes, Santiago de Chile, Tercera Edición, LexisNexis.

Selman Nahum, Arturo (2011) "Artículo 915 del CC: una solución jurisprudencial a la limitación de las acciones tradicionales", Revista Ius et Praxis, Año 17, No 1, Santiago de Chile, pp. 57-80.

Trucco, Humberto (1910) "Teoría de la posesión inscrita, dentro del CC Chileno", RDJ, tomo VII, primera parte, pp. 131-155.

Urrutia, Leopoldo (1928) "Vulgarización sobre la posesión ante el CC chilena", Revista de Derecho y Jurisprudencia, tomo XXI, primera parte, pp. 5-12. 